\title{
WOŁOSI/VLASI Z TERENÓW HERCEGOWINY W ŚWIETLE DEFTERÓW OSMAŃSKICH Z XV I XVI WIEKU
}

\author{
ILONA CZAMAŃSKA
}

\begin{abstract}
Vlachs from the area of Herzegovina in the light of Ottoman defter's from the fifteenth and sixteenth centuries

Defter's are an excellent source for historians, especially in demographic and socio-economic research, they are also very useful in researching the Vlachian communities.

Analysis of material contained in Ottoman defter's from the Herzegovina area leads to the following conclusions:

1. In the area of Herzegovina, in the second half of the fifteenth century, Vlachs lived in a mostly nomadic lifestyle. Their number was at least sixty thousand people.

2. In the second half of the fifteenth century, many abandoned villages were recorded. Abandoned villages were gradually settled by migratory Vlachs, which contributed to their change of lifestyle on semi-settled and settled. In 1585, Vlachs - shepherds who were not associated with a village were rare.

3. In the Ottoman state, Vlachs those who lead an nomadic way of living, as well as those living in the Vlachian villages, were tax-favored, paid only a lump grazing tax for the state (a filuria with allowances), and did not pay any benefits to the timar owner. In the event that they served as derbenci's or vojnuc's, they were exempted from all taxes.
\end{abstract}

4. Settling in the former agricultural villages, in particular related to undertaking agricultural activities, was most often associated with an additional burden of tithing for the sipahi. Departure from pastoralism meant degradation to a group of raya, most often in these villages mixed-agricultural-pastoral management was conducted. Newly settled villages rarely received the status of the vlachian villages, because such status freed residents from additional benefits even in the case of agricultural classes.

5. The flat-rate grazing tax, filuria, in the fifteenth century had a fixed value and equaled 45 akçe, while at the end of the sixteenth century it was different for various Vlachs groups and could range from 60 to 200 akçe. Considering the fact that additional fees for sheep or tents were liquidated and that the value of employment fell akçe significantly compared to the fifteenth century, the real amount of taxes did not increase, and in some cases it decreased.

6. Not much on the basis of defilers can be said about the language used by the Herzegovina Vlachs. In defeats from the fifteenth century they bear mostly Slavic names, but sometimes there are also names only in the Vlachs: Radu, Bratul, Dabija, the same also applies to local names.

7. Gradually, Islamization processes took place. In the fifteenth century, they are almost invisible among the Vlachs, almost all of them wore Christian names. At the end of the sixteenth century, a significant percentage of Vlachs wore Muslim names. The Islamization process seems to be faster among the Vlachs settled than the Vlachs nomads, but there is no rule.

8. In the light of the defters in the area of Herzegovina, there is no difference between Muslims and non-Muslims in burdens to the state, but defters do not include the cizye, or headship, collected from non-Muslims.

Autor: Ilona Czamańska, Uniwersytet im. Adama Mickiewicza, Instytut Historii, ul. Umultowska 89d, Poznań, Polska, czaman@amu.edu.pl, ORCID iD: https://orcid.org/0000-0002-0492-0854

Słowa kluczowe: deftery osmańskie, Vlasi, Hercegowina, osadnictwo wołoskie, prawo wołoskie, podatki od pasterstwa.

Keywords: Ottoman defters, Vlachs, Herzegovina, settlements of Vlachs, law of Vlachs, pastoral taxes. 
Balcanica Posnaniensia. Acta et studia, XXV, Poznań 2018, Wydawnictwo Instytutu Historii UAM, pp. 216249, ISBN 978-83-65663-94-8, ISSN 0239-4278. Polish text with a summary in English.

doi.org/10.14746/bp.2018.25.13

Wołosi/Vlasi ${ }^{1}$ na terenie bośniacko-dalmatyńskiego pogranicza pojawiają się sporadycznie w źródłach jeszcze w XIII wieku, a w odniesieniu do XIV i XV wieku zachowały się na ich temat całkiem liczne informacje. Zawdzięczamy je przede wszystkim systematycznie już wówczas prowadzonej kancelarii w sąsiednim Dubrowniku. Z tego też względu dość wcześnie zainteresowali się nimi badacze. Jeszcze w XIX wieku zaczął pisać na ich temat Konstantyn Jireček². Bardziej szczegółowe badania nad hercegowińskimi Vlahami w średniowieczu głównie na podstawie materiałów zachowanych w Archiwum Dubrownickim podjęli w latach pięćdziesiątych i sześćdziesiątych ubiegłego stulecia Bogomil Hrabak ${ }^{3}$ i Desanka Kovačević-Kojić4. Dzięki tym badaniom dokładnie zidentyfikowano nazwy katunów (szałasów) wołoskich prowadzących wypas na terenie Hercegowiny. O wiele trudniejsze natomiast okazało się ich usytuowanie geograficzne, zwłaszcza w odniesieniu do XIV stulecia, ponieważ źródła $\mathrm{z}$ tego okresu rzadko kiedy podają na ten temat bliższe informacje. Może to również wynikać z tego, że katuny czyli szałasy wołoskie na tym terenie prowadziły w większości wędrowny tryb życia i zapewne też nie miały ściśle określonych granic. W tym czasie jednak rozpoczął się proces stopniowej terytorializacji katunów wołoskich, prowadzący do ich osadnictwa i przechodzenia z pasterstwa w pełni wędrownego do pasterstwa transhumacyjnego. Czynnikiem sprzyjającym temu procesowi było wyjście znacznej części klanów wołoskich spod bezpośredniej władzy króla na rzecz możnowładców. Podporządkowanie katunów wołoskich poszczególnym rodom możnowładczym zanalizował niedawno Esad Kurtović. Prowadzone przez niego badania przede wszystkim w archiwum w Dubrowniku pozwoliły na wyodrębnienie licznych katunów wołoskich funkcjonujących głównie we włościach Pavloviciów, Kosačów i w znacznie mniejszej liczbie Nikoliciów. We włościach Kosačów odnotowuje on następujące katuny wołoskie: Pliščici, Gleđevici, Ugarci, Bobani, Mirilovici, Vragovici, Kresojevici, Nenkovici, Bančici, Pilatovci, Pocrnje, Drobnjaci, Riđani,

${ }^{1}$ Celowo preferuję w niniejszym artykule określenie Vlasi, związane z górską ludnością pasterską Bałkanów, w odróżnieniu od określenia Wołosi posiadającego jednoznaczną konotację etniczną związaną z księstwami rumuńskimi.

${ }^{2}$ K. Jireček, Die Wlachen und Maurowlachen in Denkmäler von Ragusa, Prag, 1879.

${ }^{3}$ Б. Храбак, О хериеговачким влашким катунима према пословной књизи дубровчанина Џивана Припчинивића, «Гласник Земаљског Музеја", 11, 1956, s. 29-39.

${ }^{4}$ Д. Ковачевић, Средњовјековни катуни по дубровачким изворима, w: Научно Друштво СР Босне и Херцеговине, Посебна издања Одељење историско филолошких наука, књига 1: Симпозијум о средњовековним катуну одржан 24. и 25 новембра 1961 г., уредник Миленко С. Филиповић, Сарајево 1963, s. 121-142. 
część katuna Manjani i część Maleševców. We włościach Pavloviciów zamieszkiwali: Vlahovici, Žurovici, Predojevici, katun Pribaca Nikolicia, część katuna Manjani i część Maleševców; a we włościach Nikoliciów katun Kutloviciów ${ }^{5}$.

Specyfika funkcjonowania Vlachów w średniowieczu, przede wszystkim jako wspólnoty klanów, spowodowała, że w materiale źródłowym częściej spotykamy nazwy klanów, niż miejsce ich przebywania.

Deftery - osmańskie spisy katastralne służyć miały przede wszystkim celom podatkowym, dziś stanowią one znakomite źródło dla historyków, zwłaszcza w badaniach demograficzno-społeczno-gospodarczych. Okazują się bardzo przydatne także w badaniach nad społecznościami wołoskimi. Nie oznacza to, że badania defterów nie dostarczają dużych trudności. Przede wszystkim jesteśmy zdani na deftery przetłumaczone i wydane drukiem. Jest ich wprawdzie dość dużo i odnoszą się one do dużej części obszarów bałkańskich, jednak bardzo często nazwy zapisywane fonetycznie są dziś trudne do identyfikacji. W interesującym nas okresie zachodziły poważne zmiany związane $\mathrm{z}$ odchodzeniem od w pełni wędrownego trybu życia i osiedlaniem się we wsiach. Rodowe nazwy katunów zastępowane były nazwami wsi, które jednak nie zawsze okazywały się trwałe. Ponadto deftery osmańskie sporządzane w różnych okresach były spisywane według zmieniających się metod i dla okręgów administracyjnych notorycznie zmieniających granice, co niekiedy utrudnia prześledzenie zmian nawet na tym samym obszarze. Pomimo tych i innych problemów deftery pozostają dla historyka źródłem, które trudno przecenić.

Najstarszy dostępny defter z badanych terenów pochodzi już z lat 1468-1469, powstał więc bardzo krótko po opanowaniu znacznej części tego terytorium przez państwo osmańskie ${ }^{6}$. Obejmuje on głównie ziemie wokół Nowego Pazaru i Sjenicy, dochodząc do Žičy na wschodzie oraz Mostaru na zachodzie. Odnotowano w nim trzy wielkie skupiska wołoskie. Jedno z nich znajdowało się w okolicach Sjenicy w okręgu określanym jako Barča lub Vrača. Spośród sześciu wsi zamieszkałych przez zajmujących się pasterstwem Vlachów: Slavogošte, Luka (domów 32), Sivča (domów 19), Zlolomišica (może Osonica domów 4), Pelević (domów 17), Donja Radotina (domów 24, opuszczonych 6) jednoznacznie daje się zidentyfikować tylko dwie: Luka (Luke) i Sivča (Sivčina). Najprawdopodobniej ten okręg wołoski Barče / Vrača znajdował się w okolicy dzisiejszego miasteczka Ivanjica. Wspomniane wsie znajdują się w bliskiej odległości od niego, a do dziś jedna z ulic w Ivanjicy nosi nazwę Starovlaška. Trudno przypuszczać, by pozostałe wsie, które trudniej zlokalizować znajdowały się w dużej odległości. Z defteru dowiadujemy się również, że 120 „niewiernych” z tego okręgu pełniło służbę strażniczą w bliżej nieokreślonym wąwozie po 40 osób w trzech miejscach jako derbendžije (pilnujący przepraw). Nie wiadomo niestety, o jaki wąwóz

${ }^{5}$ E. Kurtović, Seniori hercegovačkih vlaha, w: Hum i Hercegovina kroz povijest. Zbornik radova s međunarodnoga znanstvenog skupa održanog u Mostaru 5. i 6. studenoga 2009, uredio I. Lučić, Zagreb 2011, s. 649-695.

${ }^{6}$ Sumarni popis sandžaka Bosna iz 1468/69 godine, ed. Ahmed S. Aličić, Mostar 2008. 
tu chodzi, czy o wąwóz znajdującej się w pobliżu rzeki Morawicy, czy może raczej o nieco dalej położony, ale znacznie ważniejszy komunikacyjnie i trudniejszy pod względem terenu wąwóz rzeki Studenicy. Ogółem w okręgu Barča/Vrača miało według tego spisu zamieszkiwać 1100 rodzin wołoskich, spośród których zapewne tylko część zamieszkiwała we wsiach i posiadała ziemię (płaciła haracz - jednak od haraczu byli zwolnieni derbendžije), większa część prowadziła żywot koczowniczy trudniąc się wyłącznie pasterstwem? .

Jeszcze większe skupisko Vlachów znajdowało się w wilajecie nazywanym Hersek (Hercegowina), wówczas obejmującym okolice Mostaru. Zamieszkiwało tam ogółem 4616 rodzin vlaskich oraz 998 nieżonatych dorosłych mężczyzn. Vlasi ci płacili podatek ryczałtowy 1 filurię ( $=45$ akczy) od rodziny oraz podatek pasterski wartości 2 baranów (po 15 akczy każdy) i 2 owiec (po 12 akczy). Ponadto na każdych 50 domów należało zapłacić taksę wartości 1 namiotu w wysokości 100 akczy i dodatkowo 2 barany lub ich równowartość (tym razem po 30 akczy) $)^{8}$.

Vlasi zamieszkiwali także licznie na terytoriach określanych jako ziemie Pavlovićów. Pavlovićie przed opanowaniem Bośni przez Osmanów należeli do największych możnowładców posiadających majętności w całej południowej części królestwa Bośni (między innymi były to okolice dzisiejszego Sarajewa, Trebinje, Borač, Prač, Konavlje, Bilić i in. ), dlatego też trudno zlokalizować tę grupę Vlahów. Była ona mniej liczna od poprzedniej i liczyła 448 rodzin oraz 130 nieżonatych mężczyzn. Mieli oni takie same obciążenia podatkowe jak wspomniani wyżej Vlasi hercegowińscy, najprawdopodobniej więc prowadzili podobny tryb życia9

Niektórzy, bardzo jednak nieliczni wojewodowie wołoscy stawali się timariotami, trudno ich jednak wyłuskać bez wyraźnych wskazań, bowiem część timariotów $\mathrm{z}$ tytułem wojewody lub kneza mogła również pochodzić z dawnej serbskiej czy bośniackiej arystokracji.

Nie ma też wyraźnego wskazania czy przez Vlachów były zasiedlone wioski vojnuków. Znajdujemy tu także ciekawą informację, że pierwotnie zaliczono ich do grupy sipahich, następnie jednak zdegradowano do statusu rajów. Mimo to byli zobowiązani do służby wojskowej i zwolnieni z podatków. Możliwe, że byli to dawni krajišnicy, którzy po zmianie granic stracili swoje znaczenie, jednak wykorzystywano ich przygotowanie wojskowe i powoływano do armii. Późniejsze deftery zdają się wskazywać, że byli z pochodzenia Vlachami.

Wspomnieć też należy o 3 wsiach funkcjonujących na prawie wołoskim, jednak ich mieszkańcy najprawdopodobniej nie byli Vlachami (w defterach jednak nie ma wyraźnych wskazań na temat ich pochodzenia etnicznego). Były to trzy wsie sokolników w nahiji Drežnica (na pn. wsch. od Mostaru): Strževo - domów 62, Vrh

\footnotetext{
7 Sumarni popis sandžaka Bosna iz 1468/69, s. 26.

8 Sumarni popis sandžaka Bosna iz 1468/69, s. 67.

9 Sumarni popis sandžaka Bosna iz 1468/69, s. 69.
} 
Polja -domów 86, Knezluk - domów 55. Ich mieszkańcy płacili tylko 1 filurję podatku, nie płacili haraczu ani podatku od pasterstwa. Później żądano od nich jeszcze oddzielnie 300 francuskich dukatów, co zaznaczono w kolejnym, o wiele bardziej obszernym i szczegółowym defterze sandżaku Hercegowina spisywanym w latach $1475-1477^{10}$.

Podobnie niejasna sytuacja etniczna dotyczy wsi Rabina, której mieszkańcy pełnili funkcję derbendżijów w wąwozie Blagajnskim, czyli w wąwozie rzeki Buna. Jednak sama nazwa rzeki, jak i ukształtowanie terenu wyraźnie wskazują na obecność tam Vlachów. Imiona mieszkańców wioski były przeważnie słowiańskie, było to już jednak regułą u wszystkich miejscowych Vlachów. W zamian za pełnienie służby strażniczej mieszkańcy wioski płacili tylko podatek ryczałtowy w wysokości 1 filurii od domu i dodatkowo 85 dukatów, byli natomiast zwolnieni od wszystkich innych podatków pasterskich, co znaczy, że pasterstwo było ich głównym, obok służby strażniczej, zajęciem. Wieś była duża, liczyła 82 rodziny i 3 mężczyzn nieżonatych ${ }^{11}$.

W licznych wsiach na terenie Hercegowiny pasterstwo lub hodowla były głównym zajęciem ludności. I tak w nahiji Mileševo takich wsi było 47, w nahiji Samobor 73, w nahiji Tođevac 35, w nahiji Sokol 39, w nahiji Bistrica 17, w nahiji Dubštica 7, w nahiji Mostar 2, w nahiji Konac Polje 3, w nahiji Neretva 12, w nahiji Kukanj 22, w nahiji Dabar 1, w nahiji Popovska i Trebinje 18, w nahiji Goražde 3, w nahiji Nevesinje 3, w nahiji Zagorje 25, w nahiji Osanica 7. W wielu miejscowościach prowadzono coś w rodzaju gospodarki mieszanej. i tak np. na terenie nahiji Dabar pasterze nie wędrowali, lecz zamieszkiwali w domach. Owce i kozy przebywały na pastwisku przez okrągły rok, natomiast konie wypasano tylko w okresie letnim, a na zimę zamykano w stajniach ${ }^{12}$.

Szczególnie wiele informacji daje jednak defter z 1477 roku na temat Vlachów prowadzących tradycyjną gospodarkę pasterską. Zapisane tu zostało obowiązujące w tym sandżaku prawo pasterzy wołoskich.

Brzmi ono następująco:

Prawo dżematu [katunu, szałasu] grupy Vlachów z wilajetu Hercegowina jest następujące:

Na dzień znany pod nazwą Đurđevdan (Hizir Iljas) każdego roku dają z domu po jednej filurii i po jednej owcy z jagnięciem albo ich równowartość 12 akczy, 1 barana albo jego równowartość 15 akczy, dalej dają na każde 50 domów 2 barany albo ich równowartość 60 akczy, także na każde 50 domów 1 namiot albo jego równowartość 100 akczy, ponadto jeśli jest wojna oddają z każdych 10 domów 1 eskendżiję, który idzie na wojnę. Kiedy zostanie spełnione to, co wspomniano, są wolni od wszystkich pozostałych obowiązków ${ }^{13}$.

${ }^{10}$ Poimečni popis sandžaka vilajeta Hercegovina 1477, priredio Ahmed S. Aličić, Sarajevo 1985, s. 12.

${ }^{11}$ Tamże, s. 12-13.

12 Ђуро Тошић, Средњовјековна хумска жупа Дабар, Beograd 2005, s. 54-55.

13 Poimečni popis ...1477, s. 26. 
Defter podaje bardzo dokładne wiadomości na temat wszystkich katunów wołoskich, nazywanych tu dżematami, ich składu osobowego oraz miejsca wypasu letniego i zimowego.

Łącznie na terenie Hercegowiny w latach 1475-1477 funkcjonowało ponad 220 wędrownych katunów wołoskich nie licząc rozmaitych części wsi i dóbr klasztornych. Dokładne określenie pastwisk letnich i zimowych pozwala na wytyczenie migracji pasterzy wołoskich, istnieje jednak problem z identyfikacją wszystkich wymienionych miejsc,

Niezależnie jednak od wędrownego trybu życia niektórzy wojewodowie wołoscy posiadali też majątki ziemskie, czasem bardzo znaczne.

W niektórych nahijach, jak np. w nahiji Komarnica, zamieszkali tam Wołosi tworzyli oddziały vojnuków ${ }^{14}$. W 100 lat późniejszym defterze z roku $1585 \mathrm{w}$ tejże nahiji Komarnica odnotowano 3 wsie: Zukva, Ljeskovac Pole i Slatina funkcjonujące na prawie wołoskim. Mieszkańcy płacili tylko 1 filurię i byli zwolnieni od wszelkich innych podatków, nawet, jeśli obok pasterstwa, mieli dochody z innych zajęć ${ }^{15}$. Podobną sytuację spotykamy też zresztą w defterze z roku 1477: Isa-beg dał Pavce synu Radohne wsie Kali i Suzin. Ze wsi Kali (w odróżnieniu od wsi Suzin) nie pobierano dziesięciny od basztin wołoskich, ponieważ wieś była wołoska ${ }^{16}$. Istniała różnica w obciążeniach Wołochów zamieszkałych we wsiach na prawie wołoskim i Wołochów zamieszkałych w innych wsiach. Szczególnie widoczne staje się to w wieku XVI, w którym stopniowo zanikają katuny wołoskie nie przypisane do żadnej konkretnej wsi. Stałemu osadnictwu wołoskiemu sprzyjało wyludnienie licznych wsi oraz duża liczba opuszczonych domów i pól. Osiedlenie się jednak w takiej wsi mogło oznaczać utratę uprzywilejowanej pozycji podatkowej i konieczność opłaty dziesięciny z uprawy roli czy winnic.

Wspomniany rejestr z $1585 \mathrm{r}$. nie jest tak dokładny i nie pozwala na określenie liczby Vlachów w poszczególnych regionach, ukazuje on jednak dość istotne zmiany odnośnie podziału administracyjnego, sposobu życia i obciążeń podatkowych. Generalnie rzadko kiedy pojawia się tu termin Vlach, niemniej jednak możemy poznać Vlachów po określeniu hajman - koczownik, a także wśród mieszkańców płacących filurię.

Hajmanów nie było już wówczas nazbyt wielu. Odnotowani są w nahiji Blagaj, w której między innymi byli zobowiązani do obrony twierdzy. Mimo pasterskiego trybu życia, niektórzy tzw. koczownicy posiadali również winnice, pola i młyny we wsi Gaj, od których płacili dziesięcinę timariocie. We wsi Bunica część Vlachów posiadała gospodarstwa (baštiny) i oprócz tradycyjnej filurii (100 akcze) płaciła dziesię-

${ }^{14}$ Poimečni popis ...1477, s. 55.

${ }^{15}$ Opširni katastarski popis za oblast Hercegovu iz 1585 godine, sv. 2, dešifrao i sa osmansko-turskog jezika preveo Ahmed S. Aličić, Sarajevo 2014, s. 486-488.

${ }^{16}$ Poimečni popis ...1477, s. 604 
cinę timariocie. Vlasi-hajmani w przysiółku Rgud funkcjonowali wyłącznie na prawie wołoskim i płacili jedynie filurię w wysokości 120 akczy od gospodarstwa ${ }^{17}$.

Vlasi osiedlali się również we wsiach typowo rolniczych. Przykładem może być wieś Korotuša. Zamieszkali tam Vlasi płacili obok filurii (100 akcze) dziesięcinę spahisowi, niewątpliwie więc sami zajmowali się również rolnictwem ${ }^{18}$. W innej wsi Kukal nowo osiedleni Vlasi płacili tylko filurię $(80 \text { akczy })^{19}$, co może wskazywać, że zajmowali się wyłącznie pasterstwem.

W timarach okolicy Blagaja funkcjonowały też jeszcze tradycyjne katuny pasterskie w liczbie 46. We wsiach Kamena i Hodbina część mieszkańców płaciła dziesięcinę, część filurię, a niektórzy jedno i drugie. Podobnie we wsi Hercegov Gaj część mieszkańców zajmowała się rolnictwem, a część pasterstwem jako hajmani ${ }^{20}$.

Wsie o charakterze mieszanym spotykamy też w nahiji Dabar kazie Nevesinje, były to wsie: Zemin, Zaostra, Lapaš, Ponikva (tu Vlasi trzymali młyny). Były tu również wsie czysto wołoskie: Burmazi (z winnicą Sraški Dol), Prosina, Rasuhača, Igrinica, Krni Dol, Brdeć, Hatilj, Donji Hujiči, katun ? Kokorina w pobliżu wsi Semihovo, Vranka, Cerovi Dol ${ }^{21}$, a także Drebanj, Kapavica ${ }^{22}$

Niemal całkowicie wołoska jawi się nahija Bobani. Bobani to dziś, ale także i wówczas niewielka miejscowość w okolicach Trebinja. Znajdowały się w niej następujące wsie wołoskie: Lešnica z przysiółkami Grbica i Podplat, Rabti, Zubovići (obecnie Vlahovići), Dol'23.

Najprawdopodobniej z nowym osadnictwem wołoskim mamy do czynienia we wsiach należących do nahiji Ljubinje (kazy Nevesinje). Mieszkańcy wsi Osojna Barnos, Prisojna Barnos, Prekosela płacili ryczałtowy podatek pasterski ${ }^{24}$, ale jednak nie nazywano go filurią.

W nahiji Vidoška we wsiach Mali Dlanac, Gornji Mosor, Rastaš, Časki Dol, Košar, Cvaljine, Dračevo, Uvala, Vuđele, Dobreštica, mieszkali hajmani czyli Vlasi-pasterze płacący wyłącznie filurię różnej wysokości ${ }^{25}$. Jedynie mieszkańcy sioła Komača, mimo że byli Vlachami płacili dziesięcinę, a wieś Donja Milotina miała charakter mieszany ${ }^{26}$. W nahiji tej Vlasi mieli swoje winnice po obu stronach rzeki Radinja. Nahija Vidoška w całości była nahiją zamieszkałą przez Vlachów.

Najprawdopodobniej w całości wołoska, a $\mathrm{z}$ pewnością pasterska była nahija Popowo. W jej skład wchodziło 19 wsi (Kotezi, Orašje, Cicrina, Čavaš, Ravne,

\footnotetext{
17 Opširni katastarski popis za oblast Hercegovu iz 1585 godine, t. 2, s. 133.

18 Opširni katastarski popis za oblast Hercegovu iz 1585 godine, t. 2, s. 142.

${ }^{19}$ Opširni katastarski popis za oblast Hercegovu iz 1585 godine, t. 2, s. 144.

20 Opširni katastarski popis za oblast Hercegovu iz 1585 godine, t. 2, s. 131-135

21 Opširni katastarski popis za oblast Hercegovu iz 1585 godine, t. 2, s. 288-191

22 Opširni katastarski popis za oblast Hercegovu iz 1585 godine, t. 2, s. 191.

23 Opširni katastarski popis za oblast Hercegovu iz 1585 godine, t. 2, s. 191-192.

${ }^{24}$ Opširni katastarski popis za oblast Hercegovu iz 1585 godine, t.2, s. 194.

25 Opširni katastarski popis za oblast Hercegovu iz 1585 godine, t. 2, s. 201-203.

26 Opširni katastarski popis za oblast Hercegovu iz 1585 godine, t. 2, s. 210.
} 
Cvajlina, Mišlem, Brestica, Velika Laz, Dubljani, Jesenica, Dračevo, Kosićani, Grmljani, Poljica, Dobrešnica, Zavala, Velja Međa, Sedlari), których mieszkańcy płacili tylko ryczałt pasterski na drobne bydło czyli owce ${ }^{27}$.

W nahiji Trebinje liczne wsie wcześniej pozbawione mieszkańców zostały zasiedlone przez Vlachów (Čičevo, Poljica, Divina, Hlapina, Grnčar, Tihovo, Zasad, Gola Glavica, Gorica, Silošnica, Žuželj). Zachowali oni częściowo swój status wołoski płacąc filurię, niektórzy jednak, którzy przejęli gospodarstwa chłopskie zostali też obciążeni dziesięciną stanowiąc grupę tzw. ušurdžijów ${ }^{28}$.

W nahiji Mostar zdecydowana większość wsi miała charakter mieszany - pojedynczy Vlasi, czy też ich niewielkie grupy dosiedlali się do ludności rolniczej. Liczne były jednak również wsie w całości wołoskie, płacące podatek od pasterstwa - filurię, takich wsi było w tej nahiji ponad 20 (Opine, Kozice, Kripawa, Zemin Otoka, Dragljani, Hrestani, Sustina, Dobrkovići, Stepkovići (2x), Dobro Selo, Stojčići, Žuželj, Gradac, Biletići, Služanj, Kruševo, Međugorje, Vodice, Bogodol, Luka, Brezićani, Vapčići) $)^{29}$.

Na terenie nahiji koczowały także co najmniej 4 katuny vlaskie, a i do samego Mostaru przypisanych zostało 19 koczujących rodzin vlaskich ${ }^{30}$.

Liczni Vlasi-koczownicy zamieszkiwali też w okręgu Imota (Imocki) w 18 wsiach (Poljica, Drenovci, Gruda, Doput, Preslovica, Borinjak, Studenci, Drinovci, Podbila, Gorica, Dračevica, Vrhdol, Kozica, Rečica, Višnjica, Donji Snozin, Vinac, Brzgule (Savičići)).

W nahiji Ljubuški było w 2 połowie XVI wieku 14 wsi wołoskich (Studenči, Papratnica, Vrh Gora, Radobara, Tihaljina, Dušina, Miljetici, Čapljina (tu też młyny), Vršici, Zemin Krčevina, Dabrice, Gnilišta - nowo zasiedlona, Slatinica dawniej rolnicza, świeżo zasiedlona przez Vlachów płacących dziesięcinę, podobnie Orahovina), $z$ tego 3 nowozasiedlone na terenach rolniczych. Vlasi ci zmienili tryb życia i gospodarowania na rolniczy, zostali bowiem obciążeni opłatą dziesięciny.

W nahiji Kukanj znajdowało się w 1585 roku 15 wsi wołoskich (Šlivanska, Kneževa Njiva (nowoosiedleni Vlasi filurdžije), Gornja Paoča (nie była zasiedlona, ale znajdowała się w posiadaniu Vlachów pasterzy), Gornja Gora, Hmeljava (nowi filurdżije), Prečica (nowi filurdżije), Lehova Brda, Vrba (nowi filurdżije), Rovci, Starobrđevna Grbica, Drobnjak, Zukva, Ljeskovac Polje, Slatina, Godešina (dawniej rolnicza), Donje Ostrožile), z których 5 było nowozasiedlonych, a jedna znajdowała się w posiadaniu Vlachów pasterzy, ale nie była zamieszkana. Pozostałe wsie tej nahiji miały charakter mieszany, do takich zaliczyć należy także 5 wsi derbendżijów,

\footnotetext{
27 Opširni katastarski popis za oblast Hercegovu iz 1585 godine, t. 2, s. 279-280.

${ }^{28}$ Opširni katastarski popis za oblast Hercegovu iz 1585 godine, t. 2, s. 211-223.

${ }^{29}$ Opširni katastarski popis za oblast Hercegovu iz 1585 godine, t. 2, s.301-350.

${ }^{30}$ Opširni katastarski popis za oblast Hercegovu iz 1585 godine, t. 2, s. 280-299.
} 
zwolnionych od podatku od wypasu, co nie znaczy jednak, że pasterstwem się nie zajmowali ${ }^{31}$.

Ogółem mogło wówczas zamieszkiwać na terenie Hercegowiny ca 65-70 tys. Vlachów.

Podsumowując, analiza materiału zawartego $\mathrm{w}$ defterach osmańskich $\mathrm{z}$ terenów Hercegowiny prowadzi do następujących wniosków:

1. Na terenie Hercegowiny w 2 połowie XV wieku zamieszkiwali Vlasi prowadzący w większości wędrowny tryb życia. Liczba ich była znaczna i wynosiła co najmniej kilkadziesiąt tysięcy osób (niektórzy badacze obliczają ją na około 68 000).

2. W tym czasie doszło też z bliżej nieznanych przyczyn do katastrofy osadniczej na tym terenie i całkowitego często wyludnienia licznych wsi, co wyraźnie odnotowują deftery z lat 1468-69 i 1477. W ciągu następnego stulecia opuszczone wsie były zasiedlane przez wędrownych dotychczas Vlachów, co przyczyniło się do ich stopniowej zmiany trybu życia na półosiadły i osiadły. W 1585 roku Vlasi-pasterze nie związani z konkretną wsią byli już rzadkością.

3. W państwie osmańskim Vlasi prowadzący wędrowny tryb życia, jak też zamieszkujący we wsiach wołoskich byli uprzywilejowani podatkowo, płacili tylko ryczałtowy podatek od wypasu na rzecz państwa (filurię z dodatkami), nie płacili świadczeń na rzecz timarioty. W przypadku, gdy pełnili służbę jako derbendżije czy vojnucy byli zwalniani z wszelkich podatków.

4. Osiedlenie się w dawnych wsiach rolniczych, w szczególności związane podjęciem zajęć rolniczych, wiązało się najczęściej z dodatkowym obciążeniem dziesięciną na rzecz spahisa. Odejście od pasterstwa oznaczało degradację do grupy rajów, najczęściej więc w tych wsiach prowadzono gospodarkę mieszaną rolniczo-pasterską. W niektórych tylko wypadkach nowozasiedlone wsie otrzymywały status wsi wołoskich, co zwalniało mieszkańców od dodatkowych świadczeń nawet w przypadku podjęcia zajęć rolniczych.

5. Jednostka ryczałtowego podatku od wypasu filuria w XV wieku miała wartość stałą i równała się 45 akcze, natomiast w końcu XVI wieku była różna dla różnych grup Vlachów i mogła wynosić od 60 do 200 akcze. Biorąc pod uwagę fakt, że zlikwidowano wówczas dodatkowe opłaty za owce czy namioty i że wartość akcze znacznie spadła w porównaniu do XV wieku, realna wysokość podatków nie wzrosła, a w niektórych wypadkach uległa obniżeniu.

6. Niewiele na podstawie defterów można powiedzieć na temat języka używanego przez hercegowińskich Vlachów. W defterach z XV wieku noszą oni w większości

\footnotetext{
${ }^{31}$ Opširni katastarski popis za oblast Hercegovu iz 1585 godine, t. 2, s. 394 i n.
} 
imiona słowiańskie, niekiedy jednak zdarzają się też imiona charakterystyczne dla rumuńskich Wołochów: Radu, Bratul, Dabiża, to samo dotyczy też nazw wsi.

7. Łatwiej można określić konfesję, a zwłaszcza procesy islamizacyjne. W XV wieku są one niemal niewidoczne wśród Vlachów, niemal wszyscy nosili imiona chrześcijańskie. W końcu XVI wieku znaczny odsetek Vlachów nosił imiona muzułmańkie. Proces islamizacji zdaje się przebiegać szybciej wśród Vlachów osiadłych, niż wśród Vlachów wędrownych, ale nie ma reguły.

8. W świetle defterów nie widać różnicy w zobowiązaniach wobec państwa muzułmanów i niemuzułmanów na terenie Hercegowiny, deftery jednak nie obejmują dżizje, czyli pogłównego pobieranego od niemuzułmanów. 


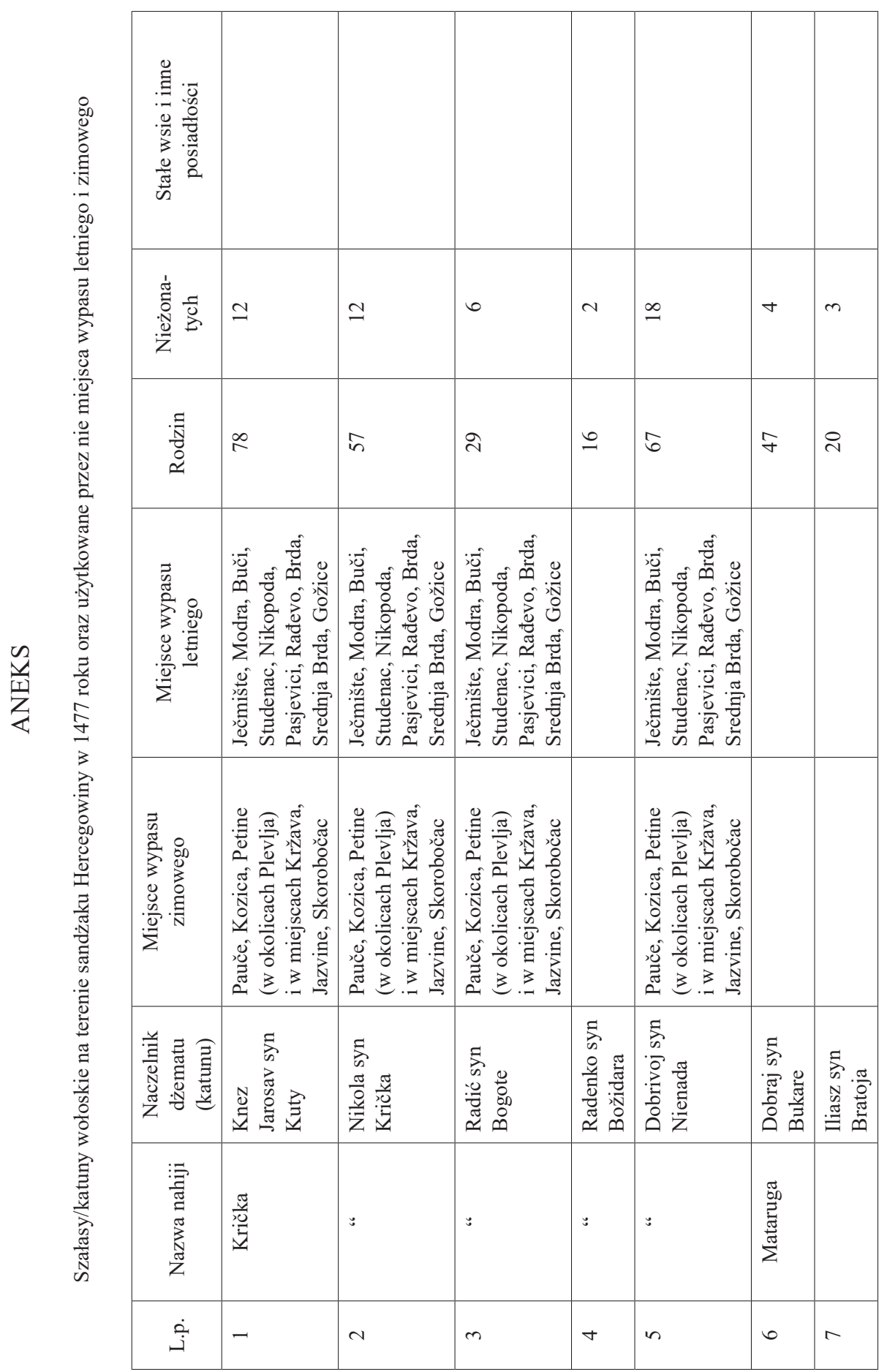




\begin{tabular}{|c|c|c|c|c|c|c|c|c|c|c|c|}
\hline 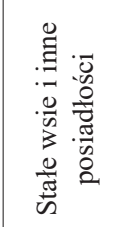 & & & & & & & & & & & \\
\hline 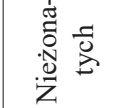 & $m$ & $m$ & & $m$ & $\nabla$ & $N$ & \pm & $r$ & $m$ & & $\nabla$ \\
\hline$\frac{\mathbb{N}}{\mathscr{0}}$ & in & $\hat{\imath}$ & $\stackrel{\infty}{\sim}$ & $m$ & $\vec{m}$ & 2 & f & in & กี & 0 & $\bar{m}$ \\
\hline 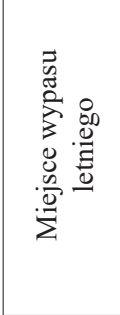 & 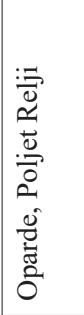 & & & & 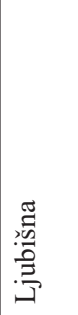 & 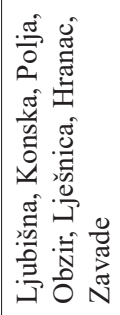 & 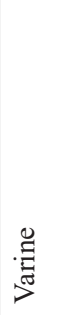 & 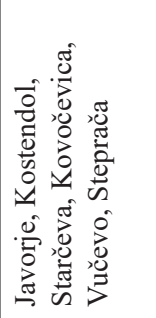 & 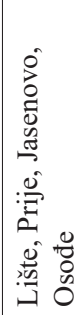 & & 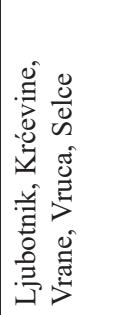 \\
\hline 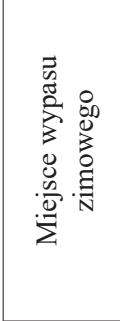 & 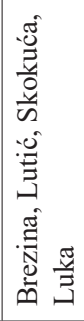 & & & & 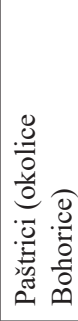 & 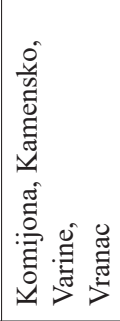 & 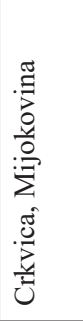 & 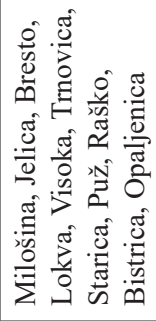 & 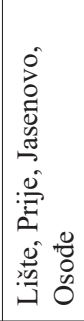 & & 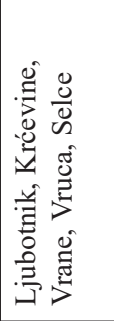 \\
\hline 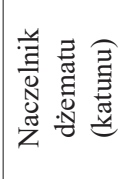 & 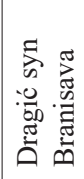 & 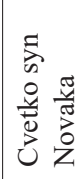 & 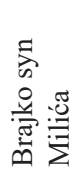 & 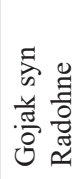 & 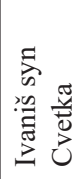 & 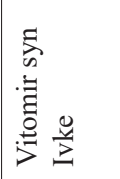 & 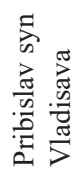 & 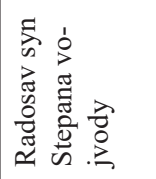 & 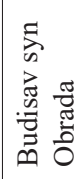 & 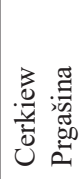 & 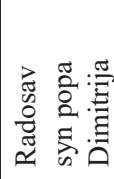 \\
\hline 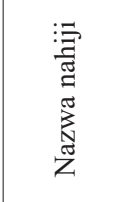 & & 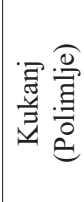 & & & & & & 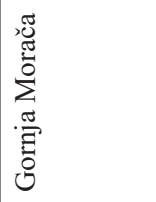 & 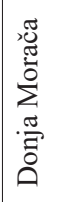 & : & : \\
\hline به & $\infty$ & $a$ & 으 & $=$ & $\simeq$ & $\cong$ & \pm & $\stackrel{2}{2}$ & 0 & $\beth$ & $\infty$ \\
\hline
\end{tabular}




\begin{tabular}{|c|c|c|c|c|c|c|c|c|c|c|c|c|c|}
\hline$m$ & in & $\stackrel{d}{\sim}$ & $\nabla$ & & $m$ & $\nabla$ & in & - & $\sim$ & - & - & $a$ & $N$ \\
\hline$\stackrel{\infty}{\sim}$ & $\stackrel{\sim}{m}$ & $\cong$ & $\hat{\imath}$ & $r$ & $\approx$ & $\vec{\sim}$ & $\theta$ & $\stackrel{0}{-}$ & $a$ & $a$ & $a$ & $\simeq$ & 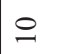 \\
\hline 莺 & 莺 & 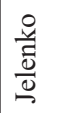 & 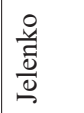 & 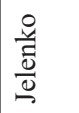 & 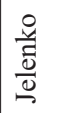 & 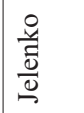 & 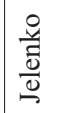 & 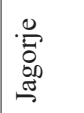 & 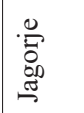 & 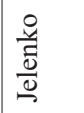 & 苞 & a. & 莺 \\
\hline 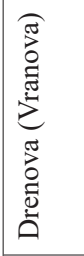 & 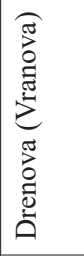 & : & 苞 & $\stackrel{\mathscr{B}}{:}$ & 苞 & 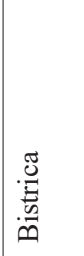 & 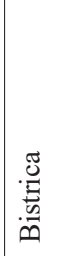 & 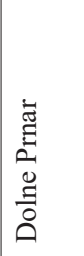 & 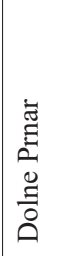 & 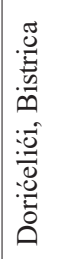 & 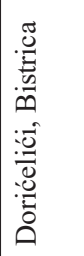 & : & 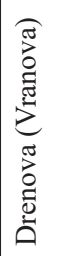 \\
\hline 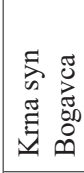 & 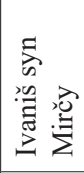 & 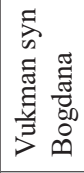 & 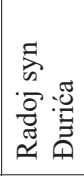 & 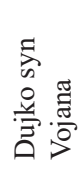 & 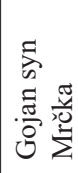 & 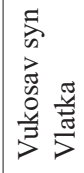 & 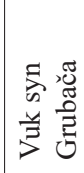 & 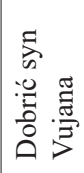 & 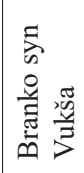 & 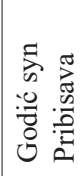 & 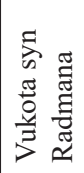 & 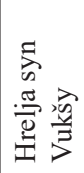 & 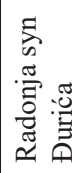 \\
\hline 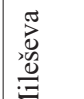 & : & : & : & : & : & : & : & : & : & : & : & : & : \\
\hline$\stackrel{2}{2}$ & $\stackrel{\sim}{~}$ & $\vec{\sim}$ & ปี & $\tilde{\imath}$ & $\stackrel{d}{d}$ & $\stackrel{2}{2}$ & $\stackrel{\sim}{\sim}$ & $\hat{\imath}$ & $\stackrel{\infty}{N}$ & શे & i & $\bar{m}$ & $\stackrel{N}{n}$ \\
\hline
\end{tabular}




\begin{tabular}{|c|c|c|c|c|c|c|c|c|c|c|}
\hline 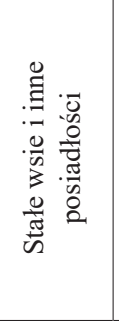 & & & & & & & & & & 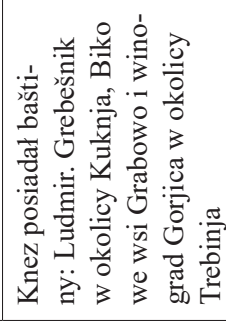 \\
\hline 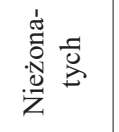 & $N$ & $N$ & + & $\Xi$ & in & $r$ & & in & 0 & 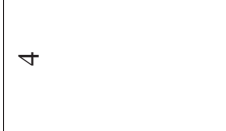 \\
\hline $\begin{array}{l}\text { 芯 } \\
\text { 兄 }\end{array}$ & $\ddot{\sim}$ & $\stackrel{0}{0}$ & $\underline{-}$ & fo & 1 & $\hat{\imath}$ & $\simeq$ & $a$ & \pm & $n$ \\
\hline 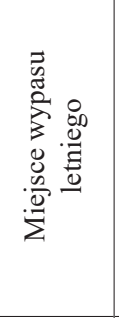 & 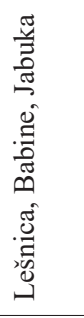 & 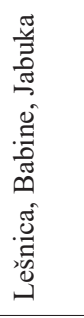 & 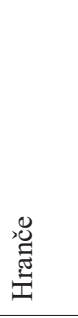 & $\frac{\ddot{z}}{\frac{\pi}{*}}$ & $\frac{\ddot{y}}{\vec{y}}$ & 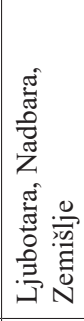 & 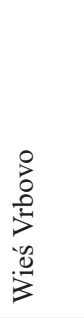 & $\begin{array}{l}0 \\
0 \\
0 \\
0 \\
0 \\
0 \\
3 \\
0 \\
0 \\
0 \\
0 \\
0\end{array}$ & 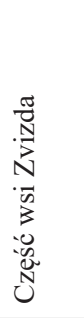 & 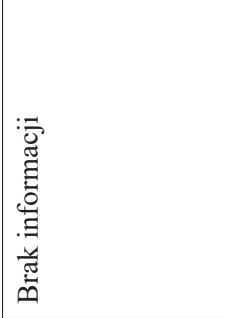 \\
\hline 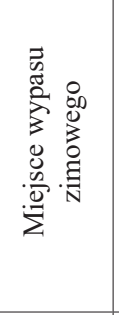 & 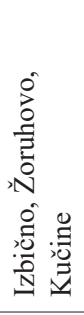 & 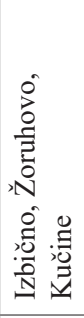 & $\begin{array}{l}\frac{\pi}{N} \\
\frac{N}{N}\end{array}$ & 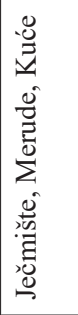 & 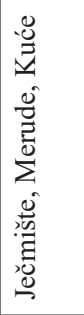 & 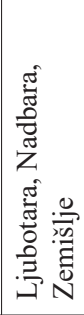 & 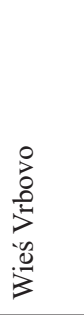 & $\begin{array}{l}0 \\
0 \\
0 \\
0 \\
0 \\
0 \\
3 \\
0 \\
0.0 \\
0 \\
0 \\
0\end{array}$ & 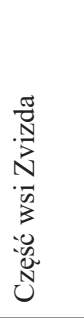 & 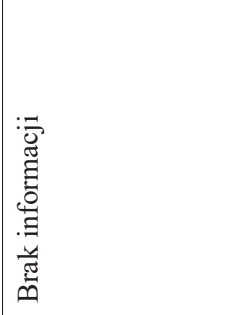 \\
\hline 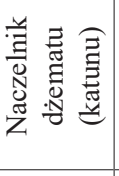 & 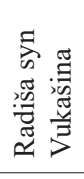 & 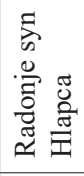 & 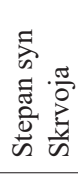 & 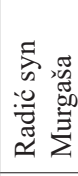 & 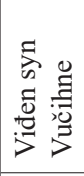 & 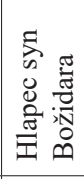 & 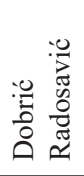 & 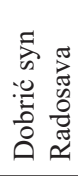 & 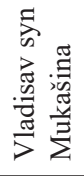 & 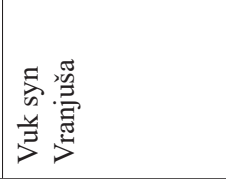 \\
\hline 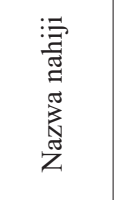 & $:$ & $:$ & : & : & $:$ & $:$ & : & : & $:$ & 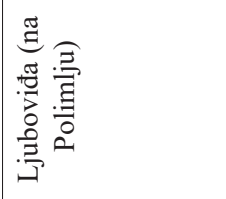 \\
\hline بُ & $m$ & m & $\stackrel{m}{m}$ & $m$ & $\hat{m}$ & $\stackrel{\infty}{m}$ & & ले & q & $F$ \\
\hline
\end{tabular}




\begin{tabular}{|c|c|c|c|c|c|}
\hline in & in & $\nabla$ & $m$ & $\nabla$ & $n$ \\
\hline I & $\stackrel{\Delta}{\sim}$ & $\nabla$ & $\simeq$ & Ұ & $\Xi$ \\
\hline 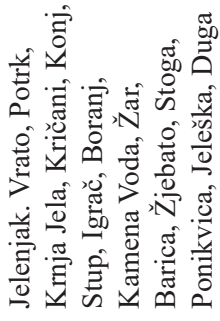 & 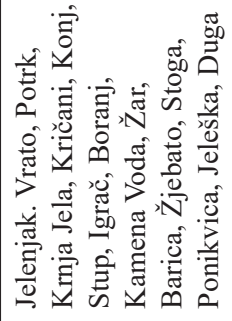 & 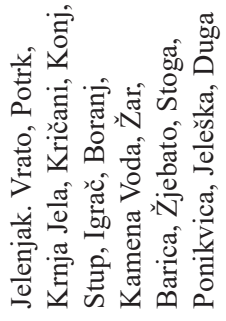 & 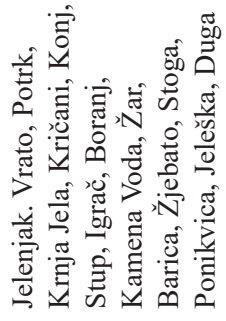 & 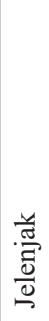 & 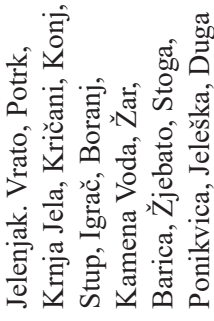 \\
\hline 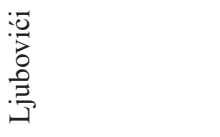 & 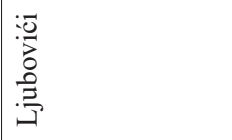 & 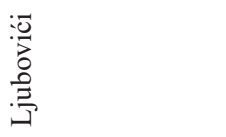 & 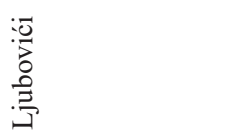 & 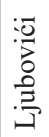 & 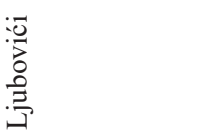 \\
\hline 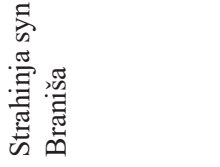 & 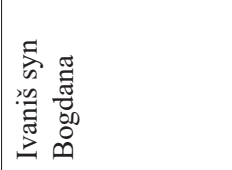 & 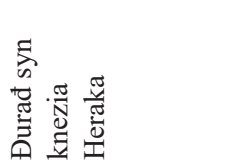 & 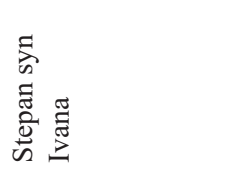 & 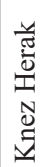 & 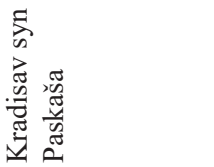 \\
\hline 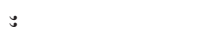 & : & s & : & : & S \\
\hline$\stackrel{\mathcal{F}}{ }$ & $\mathscr{f}$ & ষ & $\stackrel{\wp}{*}$ & fo & F \\
\hline
\end{tabular}




\begin{tabular}{|c|c|c|c|c|c|c|c|c|c|c|}
\hline 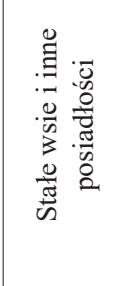 & & 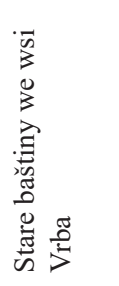 & 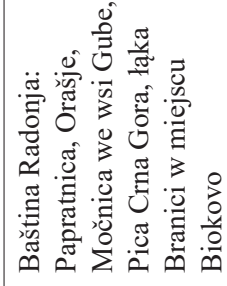 & & & 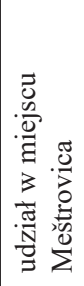 & & & & \\
\hline 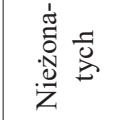 & $r$ & $\nabla$ & $m$ & $=$ & in & $N$ & $\nabla$ & $\sim$ & in & $m$ \\
\hline $\begin{array}{l}\text { 击 } \\
\text { 号 }\end{array}$ & in & 우 & $\cong$ & n & $\hat{\imath}$ & $\infty$ & ন & $\infty$ & 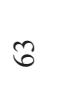 & $\approx$ \\
\hline 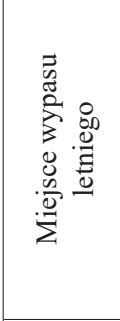 & 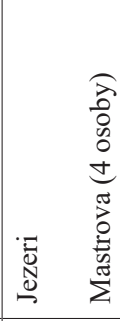 & 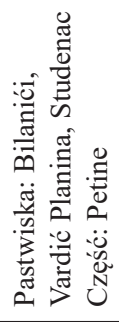 & & 苞 & 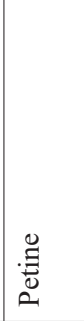 & 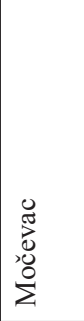 & 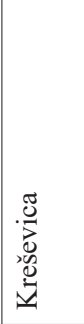 & 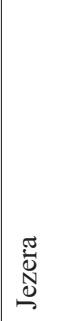 & 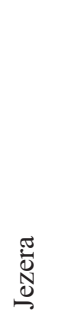 & 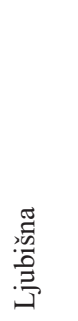 \\
\hline 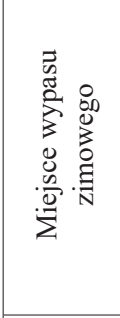 & 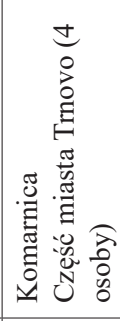 & 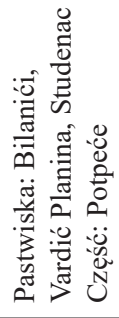 & 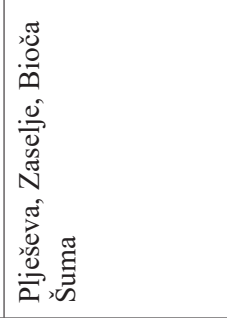 & 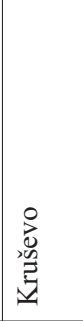 & 莺 & 窇 & 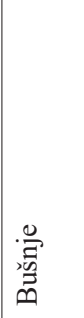 & 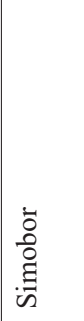 & 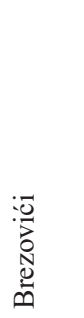 & $\frac{\stackrel{0}{\vec{d}}}{\stackrel{\vec{d}}{\mathbb{N}}}$ \\
\hline 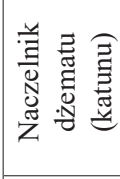 & 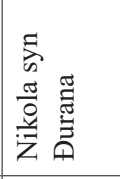 & 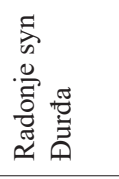 & 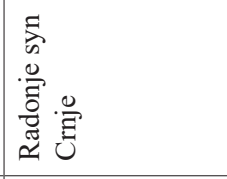 & 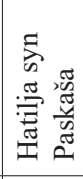 & 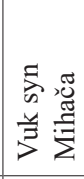 & 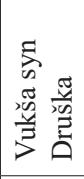 & 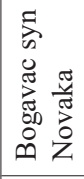 & 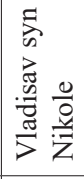 & 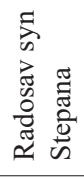 & 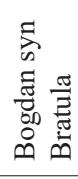 \\
\hline 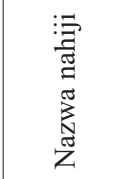 & 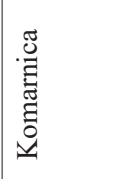 & : & : & $\therefore$ & : & : & : & : & : & : \\
\hline نُ & $\stackrel{\infty}{+}$ & $\stackrel{g}{f}$ & in & $\bar{n}$ & $\tilde{n}$ & in & 点 & $i n$ & $\stackrel{\circ}{n}$ & in \\
\hline
\end{tabular}




\begin{tabular}{|c|c|c|c|c|c|c|c|c|c|c|c|}
\hline & & 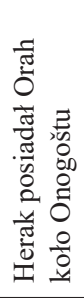 & & & & & & 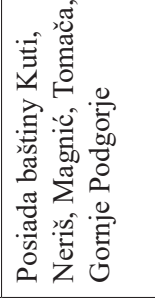 & & & \\
\hline$\nabla$ & $N$ & $\sim$ & $n$ & & & & & & & & \\
\hline$\stackrel{\infty}{+}$ & 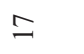 & 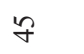 & $\infty$ & $\bar{n}$ & $=$ & i & $a$ & $\vec{\sim}$ & $\bar{n}$ & $\forall$ & $\hat{6}$ \\
\hline 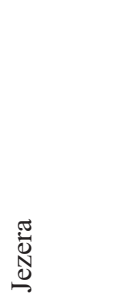 & $\begin{array}{l}\stackrel{\widetilde{3}}{N} \\
\stackrel{N}{\sim}\end{array}$ & $\begin{array}{l}\stackrel{\widetilde{3}}{N} \\
\stackrel{N}{\sim}\end{array}$ & 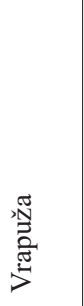 & 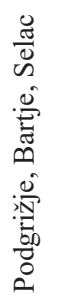 & & & & 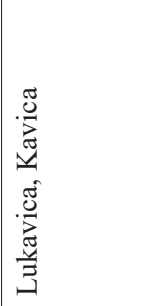 & 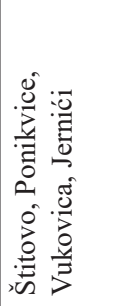 & & \\
\hline 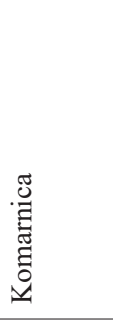 & 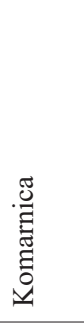 & 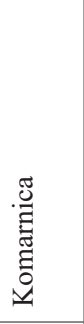 & $\frac{\pi}{0}$ & 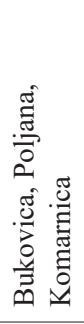 & & & & 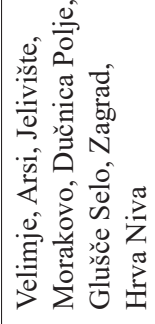 & 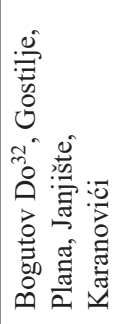 & & \\
\hline 总营 & 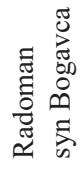 & 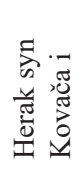 & 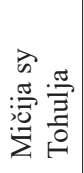 & 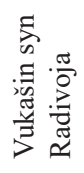 & 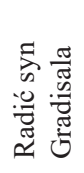 & 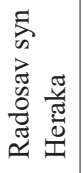 & 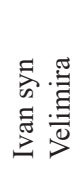 & 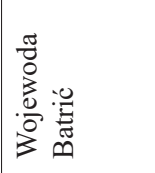 & 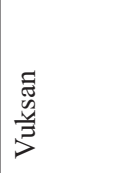 & 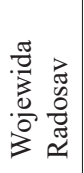 & 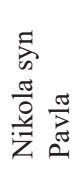 \\
\hline : & : & : & : & $:$ & : & : & : & 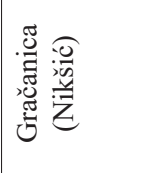 & $\begin{array}{l}\overline{0} \\
\tilde{o} \\
\simeq\end{array}$ & 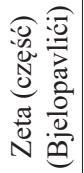 & : \\
\hline$\stackrel{\infty}{n}$ & in & 8 & $\vec{\sigma}$ & $\widetilde{\sigma}$ & $\tilde{6}$ & t & $\sqrt{6}$ & 8 & $\hat{\sigma}$ & $\infty$ & oิ \\
\hline
\end{tabular}




\begin{tabular}{|c|c|c|c|c|c|c|c|c|c|c|c|c|}
\hline 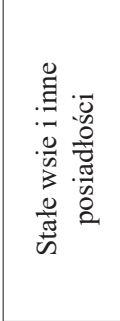 & & & & 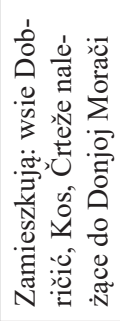 & 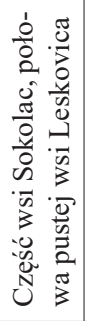 & 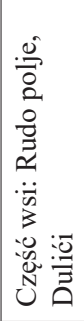 & & 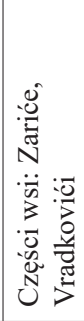 & 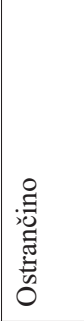 & & 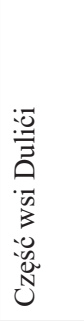 & \\
\hline 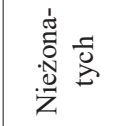 & & & & $\nabla$ & $\sim$ & & & & & & & \\
\hline 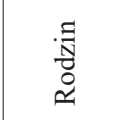 & $\stackrel{\sim}{n}$ & $n$ & $=$ & r & $\stackrel{\infty}{\sim}$ & 우 & $r$ & $=$ & $=$ & $\stackrel{\sim}{\sim}$ & $\tilde{\imath}$ & ిల \\
\hline 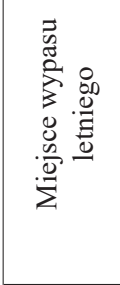 & & & 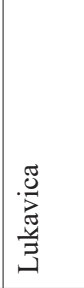 & & 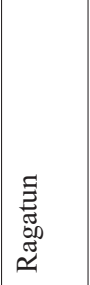 & 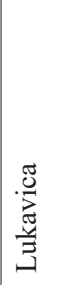 & & & : & 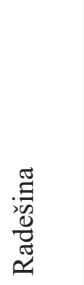 & 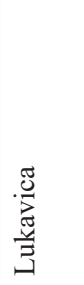 & 节 \\
\hline 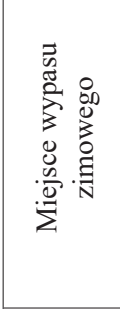 & & & 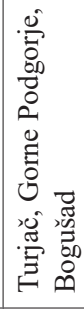 & & $\stackrel{0}{\stackrel{0}{\Xi}}$ & 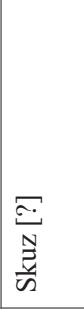 & & & 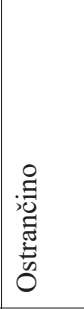 & 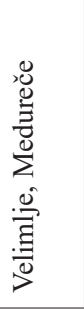 & 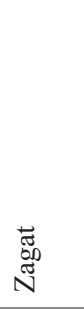 & 滒 \\
\hline 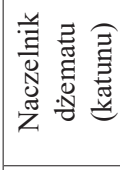 & 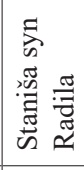 & 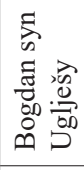 & 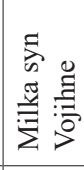 & 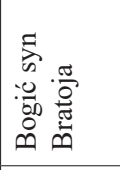 & 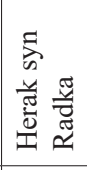 & 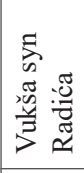 & 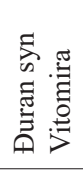 & 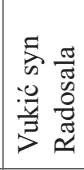 & 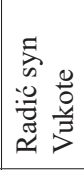 & 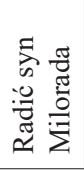 & 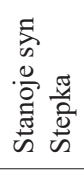 & 告 \\
\hline 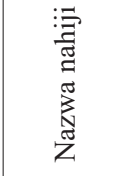 & : & : & $\begin{array}{l}\text { 盛 } \\
0 \\
0 \\
0 \\
0 \\
0\end{array}$ & : & 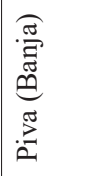 & : & : & : & & & & \\
\hline$\stackrel{\dot{\varphi}}{\dot{i}}$ & 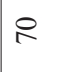 & $\nabla$ & $\sqrt{2}$ & 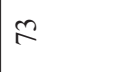 & 亲 & $\stackrel{2}{2}$ & $\stackrel{0}{2}$ & 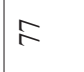 & $\stackrel{\infty}{\sim}$ & 9 & $\infty$ & $\bar{\infty}$ \\
\hline
\end{tabular}




\begin{tabular}{|c|c|c|c|c|c|c|c|c|c|c|}
\hline & & 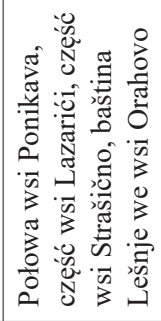 & 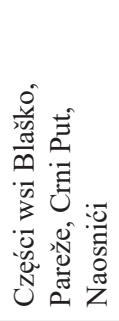 & 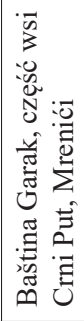 & & & 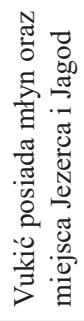 & & 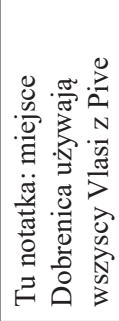 & 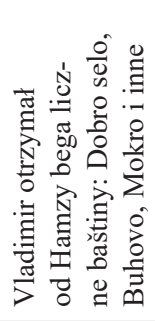 \\
\hline & & & & & & & & & & \pm \\
\hline$\approx$ & $\infty$ & $m$ & $\vec{m}$ & ले & $\infty$ & \pm & 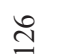 & $\stackrel{\infty}{\sim}$ & 0 & $\infty$ \\
\hline 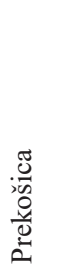 & $\begin{array}{l}\frac{\pi}{\pi} \\
0 \\
\stackrel{\vec{\Xi}}{\Sigma} \\
\dot{\Sigma}\end{array}$ & 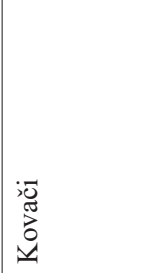 & & & $\begin{array}{l}\overline{0} \\
\stackrel{\Xi}{\Xi} \\
\stackrel{0}{\varrho}\end{array}$ & 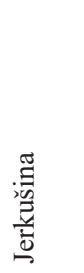 & 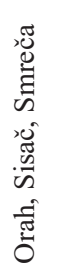 & 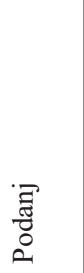 & & \\
\hline 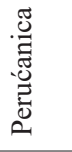 & 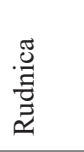 & 营 & & 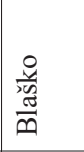 & $\begin{array}{l}\frac{0}{0} \\
\frac{\pi}{0} \\
\frac{1}{0}\end{array}$ & 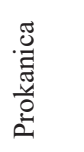 & 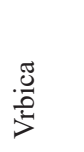 & 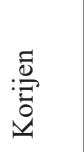 & & \\
\hline 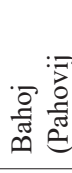 & 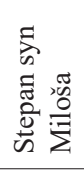 & 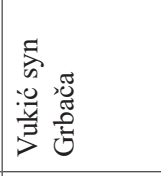 & 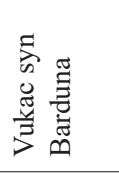 & 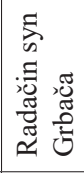 & 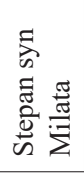 & 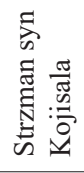 & 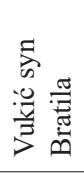 & 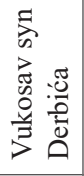 & 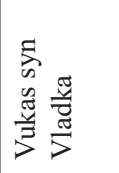 & 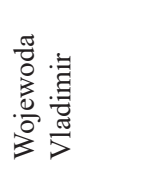 \\
\hline & & & & & & & & & & 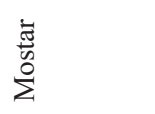 \\
\hline$\widetilde{\infty}$ & $\tilde{\infty}$ & ప & $\mathscr{\infty}$ & $\infty$ & $\hat{\infty}$ & $\infty$ & $\infty$ & \& & $\bar{a}$ & ส̃ \\
\hline
\end{tabular}




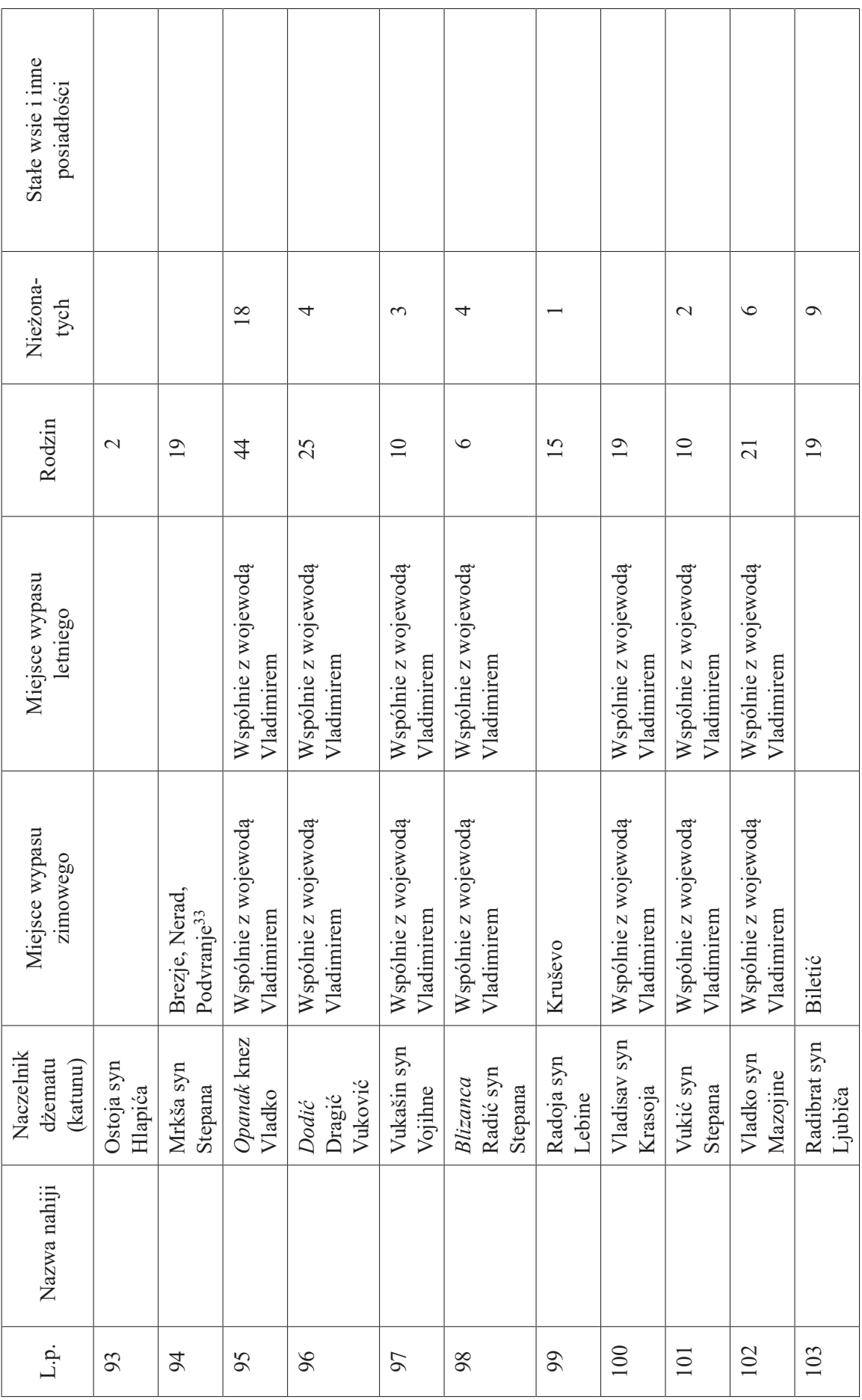

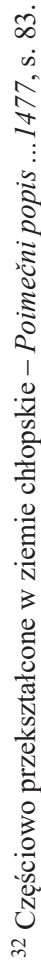




\begin{tabular}{|c|c|c|c|c|c|c|c|c|}
\hline & & $m$ & in & & & & & \\
\hline$n m b n m d$ & $\forall 0 n$ & $\hat{\sim}$ & $=$ & $=$ & 8 & $\stackrel{0}{=}$ & $\approx$ & $\stackrel{q}{q}$ \\
\hline 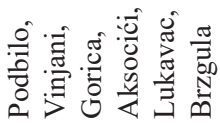 & 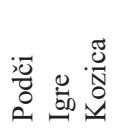 & 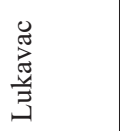 & 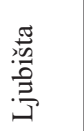 & & & & & \\
\hline 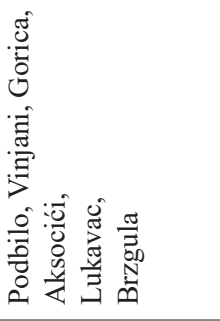 & 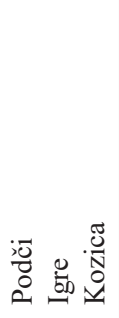 & 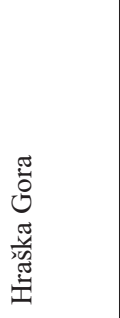 & 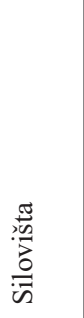 & 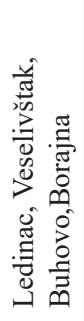 & & 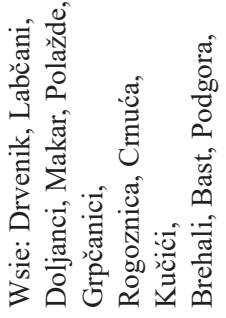 & 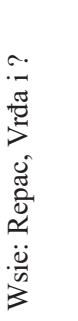 & 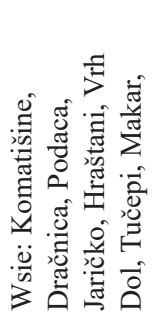 \\
\hline 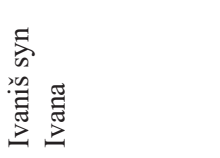 & 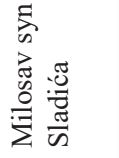 & 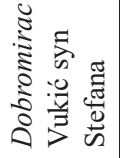 & 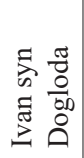 & 总 & 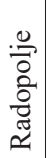 & $\begin{array}{l}\overline{8} \\
\overline{0} \\
\overline{0}\end{array}$ & 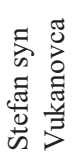 & 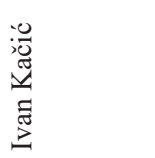 \\
\hline $\begin{array}{l}\frac{\pi}{0} \\
0 \\
\Xi\end{array}$ & & & & 罡 & & & & \\
\hline$\stackrel{t}{0}$ & $\stackrel{2}{0}$ & $\stackrel{0}{0}$ & 으 & $\stackrel{\infty}{\varrho}$ & $\stackrel{\circ}{0}$ & $\stackrel{ }{=}$ & $\Xi$ & $\stackrel{\beth}{=}$ \\
\hline
\end{tabular}




\begin{tabular}{|c|c|c|c|c|c|c|c|c|c|c|c|c|c|}
\hline 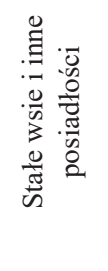 & & 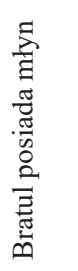 & & & & & & & & & & & \\
\hline 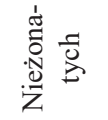 & $\sim$ & $m$ & $\nabla$ & & $n$ & $\nabla$ & $\nabla$ & $\nabla$ & 0 & $\nabla$ & $\sim$ & $m$ & \\
\hline 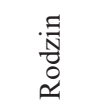 & $\infty$ & 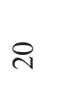 & กี & 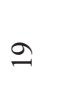 & 0 & กี & 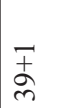 & mे & $\tilde{f}$ & in & $\widetilde{N}$ & $\tilde{\lambda}$ & \pm \\
\hline 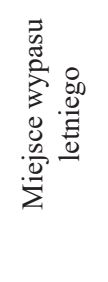 & $\frac{\mathscr{N}}{\bar{m}}$ & 兽 & 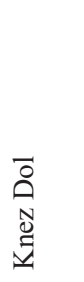 & & 恚 & $\stackrel{\mathscr{\Xi}}{\leftrightarrows}$ & & & & 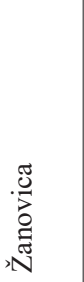 & 胥 & 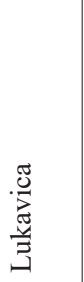 & 尊 \\
\hline 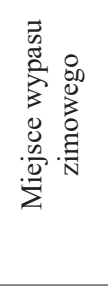 & 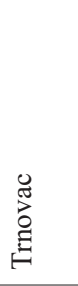 & 衤 & $\begin{array}{l}\overline{0} \\
\stackrel{0}{0} \\
0 \\
0 \\
0\end{array}$ & & 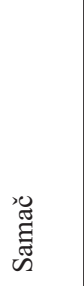 & 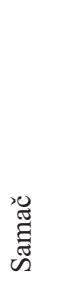 & & 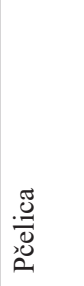 & & 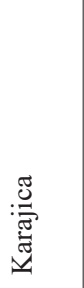 & 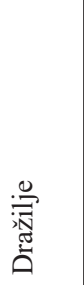 & 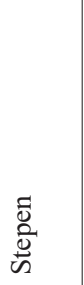 & $\begin{array}{l}\stackrel{0}{0} \\
\stackrel{\infty}{0}\end{array}$ \\
\hline 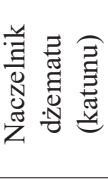 & 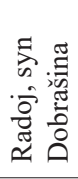 & 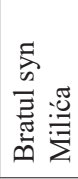 & 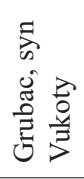 & 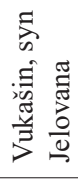 & 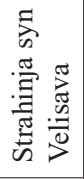 & 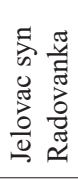 & 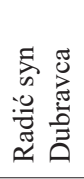 & 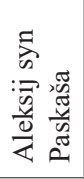 & 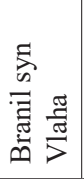 & 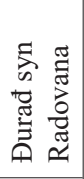 & 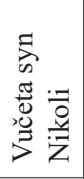 & 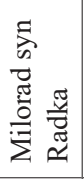 & 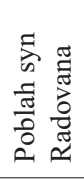 \\
\hline 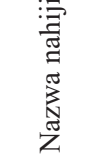 & 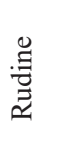 & & & & & & & & & & & & \\
\hline نُ & $\stackrel{M}{=}$ & $\stackrel{\Xi}{\Xi}$ & $\cong$ & $\stackrel{\circ}{=}$ & 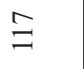 & $\stackrel{\infty}{=}$ & $\stackrel{\partial}{\exists}$ & 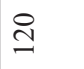 & 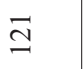 & తี & $\cong$ & $\stackrel{\Xi}{\beth}$ & $\cong$ \\
\hline
\end{tabular}




\begin{tabular}{|c|c|c|c|c|c|c|c|c|c|c|c|}
\hline & & & & 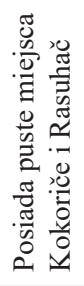 & & & & & 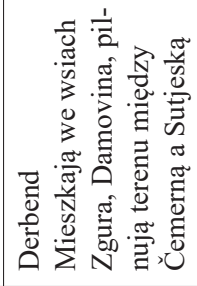 & & \\
\hline$\nabla$ & in & $\sim$ & $r$ & 0 & $m$ & $a$ & 0 & $n$ & $r$ & & 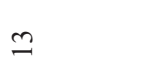 \\
\hline$\stackrel{\Delta}{\sim}$ & q & $a$ & $i$ & f & in & $\vec{n}$ & $\stackrel{\infty}{\sim}$ & $\forall$ & $\vec{\sim}$ & $\because$ & 2 \\
\hline 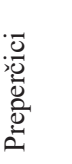 & & & 总 & & 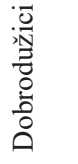 & 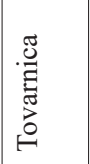 & 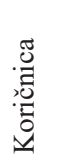 & 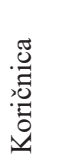 & & $\begin{array}{l}\overline{0} \\
\stackrel{0}{0} \\
\simeq\end{array}$ & \\
\hline$\frac{\tilde{J}}{\tilde{\Xi}}$ & $\stackrel{\mathscr{D}}{\mathscr{D}}$ & 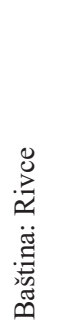 & 营 & 章 & 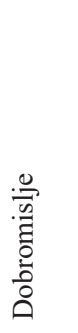 & שֶ & 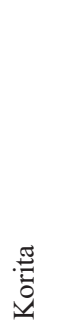 & 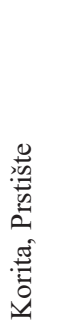 & & $\frac{9}{\ddot{g}}$ & 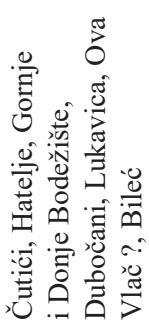 \\
\hline 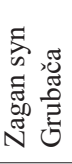 & 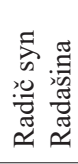 & 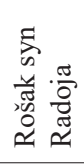 & 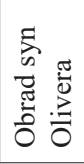 & 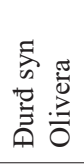 & 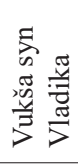 & 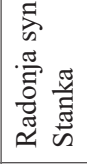 & 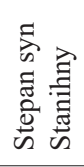 & 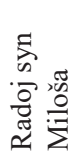 & 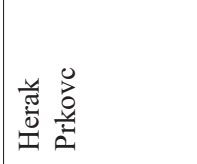 & 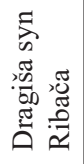 & 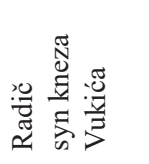 \\
\hline 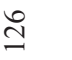 & $\widehat{\beth}$ & $\stackrel{\infty}{\simeq}$ & $\stackrel{\beth}{\beth}$ & $\stackrel{\text { D }}{=}$ & 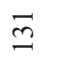 & $\stackrel{\sim}{\sim}$ & $\underline{m}$ & $\vec{m}$ & $\stackrel{n}{2}$ & 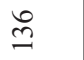 & $\hat{m}$ \\
\hline
\end{tabular}




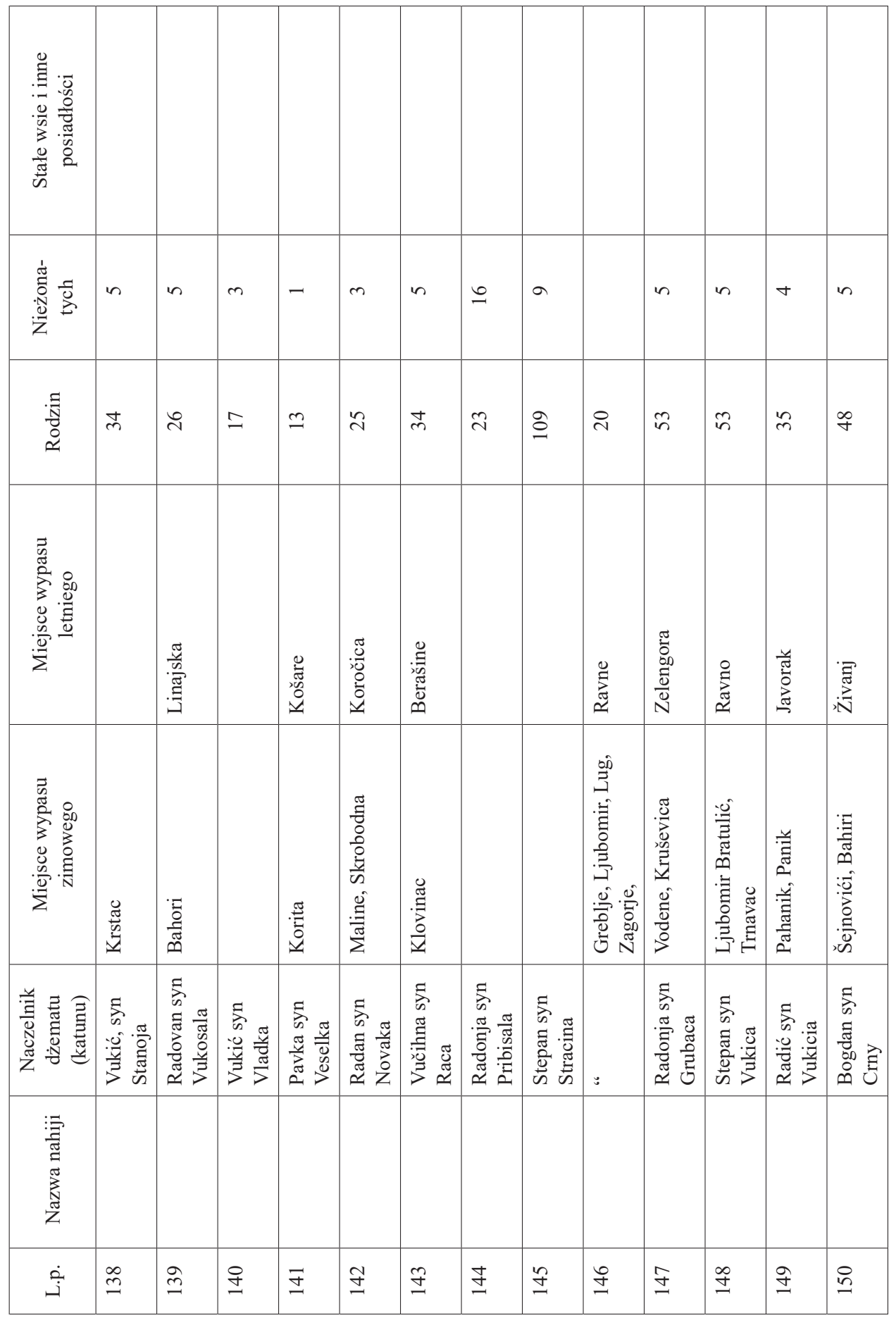




\begin{tabular}{|c|c|c|c|c|c|c|c|c|c|c|c|c|}
\hline & & & & & & & 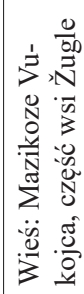 & & & & & \\
\hline 0 & $\sim$ & $\nabla$ & in & & & $=$ & & & & $m$ & $\stackrel{\infty}{\sim}$ & $\infty$ \\
\hline i & 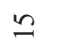 & $\stackrel{\sim}{\sim}$ & $\mathscr{F}$ & $=$ & fo & $\stackrel{\infty}{\circ}$ & 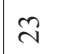 & $\ddot{m}$ & 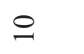 & $\ddot{\imath}$ & $\mathscr{F}$ & ণ \\
\hline 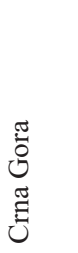 & 词 & 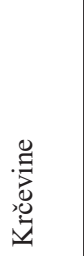 & 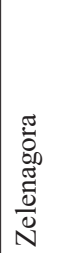 & $\begin{array}{l}: \overline{0} \\
\overline{0} \\
x \\
0 \\
\simeq \\
\simeq\end{array}$ & & $\begin{array}{l}\text { 总 } \\
\text { 惫 }\end{array}$ & & 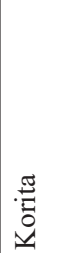 & & 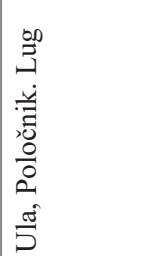 & $\underset{\Xi}{\Xi}$ & $\underset{\Xi}{\Xi}$ \\
\hline 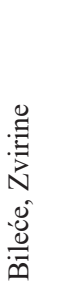 & 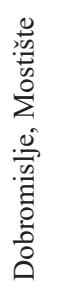 & $\begin{array}{l}\frac{0}{0} \\
5\end{array}$ & 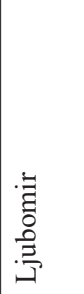 & 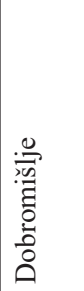 & & 竞 & & $\begin{array}{l}\overline{0} \\
\bar{g} \\
\bar{z}\end{array}$ & & 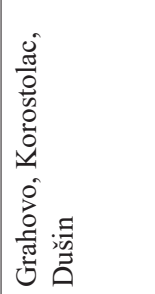 & $\begin{array}{l}\frac{\pi}{E} \\
\frac{\pi}{0} \\
\text { N } \\
\text { N }\end{array}$ & $\begin{array}{l}\frac{\pi}{E} \\
\text { 荧 } \\
\text { N }\end{array}$ \\
\hline 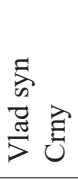 & 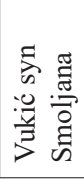 & 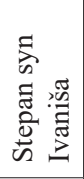 & 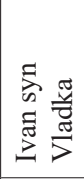 & 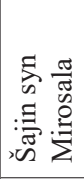 & 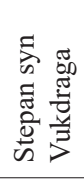 & 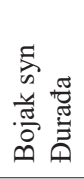 & 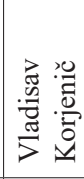 & 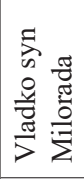 & 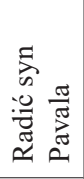 & 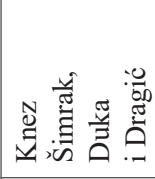 & 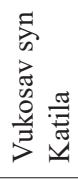 & 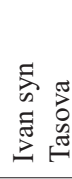 \\
\hline & & & & & & 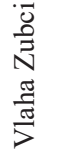 & $\begin{array}{l}\ddot{z} \\
\stackrel{0}{0} \\
\underline{\underline{u}}\end{array}$ & 葋 & & & 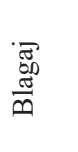 & \\
\hline $\bar{n}$ & $\approx$ & $\tilde{n}$ & 点 & $\stackrel{n}{n}$ & $\stackrel{\circ}{2}$ & $\hat{n}$ & $\stackrel{\infty}{n}$ & î & $\stackrel{8}{\circ}$ & $\overrightarrow{0}$ & $\widetilde{\sigma}$ & $\tilde{6}$ \\
\hline
\end{tabular}




\begin{tabular}{|c|c|c|c|c|c|c|c|c|c|c|c|}
\hline 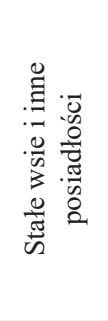 & & & 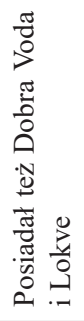 & & & & & & & & \\
\hline 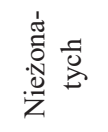 & $r$ & 0 & $m$ & $N$ & - & in & ナ & $\nabla$ & $\sim$ & \pm & in \\
\hline $\begin{array}{l}\text { 零 } \\
\text { 品 }\end{array}$ & \pm & $\grave{\cong}$ & ) & 으 & $a$ & Әे & ৯े & 우 & $\stackrel{\sim}{2}$ & $\stackrel{\infty}{\circ}$ & $\bar{m}$ \\
\hline 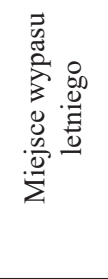 & 节 & 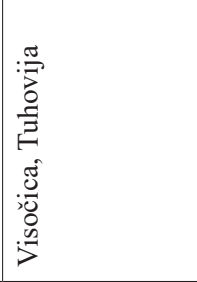 & & & 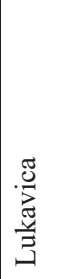 & 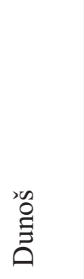 & 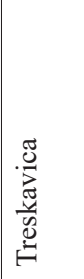 & 总 & 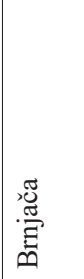 & 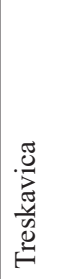 & 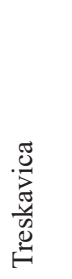 \\
\hline 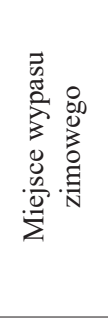 & Uَّ & 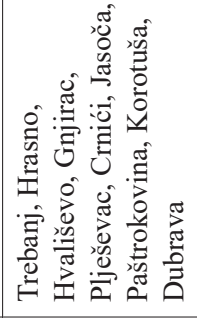 & 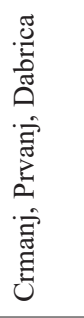 & & 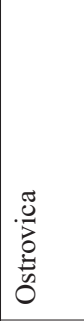 & $\begin{array}{l}\overrightarrow{Z_{0}} \\
\widetilde{\sigma_{0}}\end{array}$ & 尝 & $\begin{array}{l}\frac{\pi}{\pi} \\
\frac{2}{0} \\
2\end{array}$ & 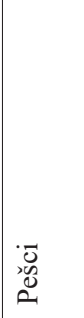 & 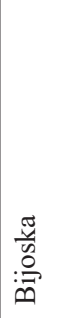 & $\begin{array}{l}\frac{\pi}{\tilde{\pi}} \\
\tilde{\tilde{a}} \\
\tilde{\sigma}\end{array}$ \\
\hline 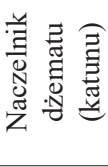 & 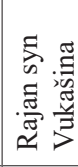 & 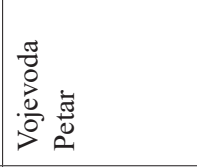 & 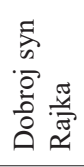 & 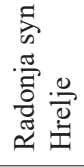 & 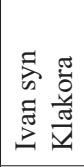 & 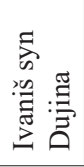 & 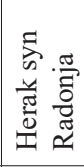 & 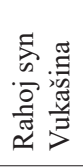 & 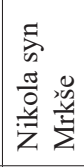 & 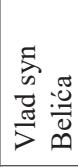 & 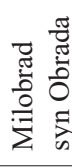 \\
\hline 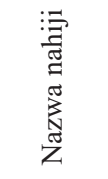 & & & & & & & & & & & \\
\hline نُ & ț & 6 & $\stackrel{0}{0}$ & $\hat{0}$ & $\stackrel{\infty}{\infty}$ & oి & 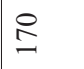 & ㅍ & 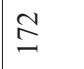 & $\cong$ & $\stackrel{ \pm}{\Xi}$ \\
\hline
\end{tabular}




\begin{tabular}{|c|c|c|c|c|c|c|c|c|c|c|c|c|}
\hline$\nabla$ & $m$ & $m$ & N & N & $m$ & & $N$ & $m$ & $m$ & $m$ & in & $\nabla$ \\
\hline d & $\infty$ & i্ & $I$ & $\underline{n}$ & $=$ & 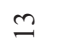 & 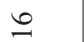 & $\stackrel{\infty}{+}$ & 9 & 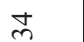 & $\approx$ & $\hat{\imath}$ \\
\hline $\begin{array}{l}\text { ज्ञ్ } \\
\text { Uี }\end{array}$ & 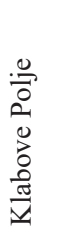 & 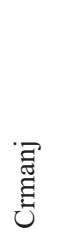 & $\stackrel{\mathscr{E}}{\stackrel{0}{0}}$ & $\stackrel{\stackrel{\Xi}{0}}{\stackrel{0}{\Sigma}}$ & 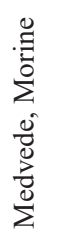 & & & $\frac{\mathscr{\Xi}}{\stackrel{\Xi}{\Xi}}$ & 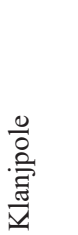 & $\stackrel{\mathscr{\Xi}}{\stackrel{\Xi}{\Xi}}$ & 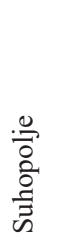 & $\frac{\mathscr{\Xi}}{\stackrel{\Xi}{0}}$ \\
\hline 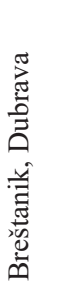 & 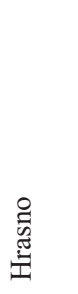 & 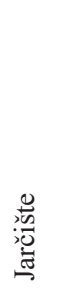 & 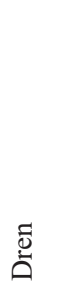 & 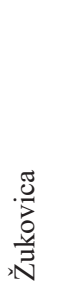 & 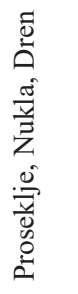 & & 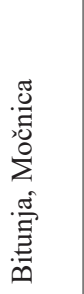 & 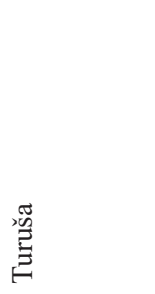 & 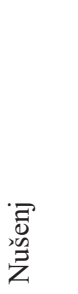 & 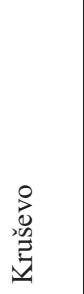 & 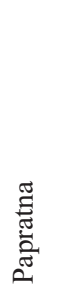 & 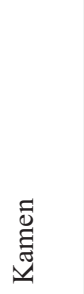 \\
\hline 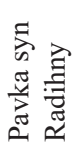 & 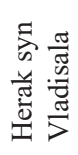 & 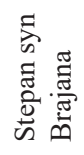 & 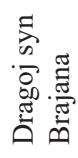 & 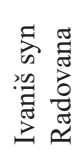 & 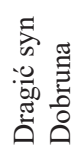 & 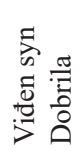 & 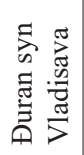 & 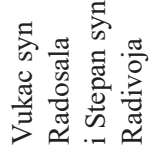 & 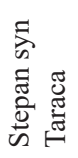 & 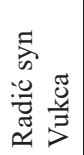 & 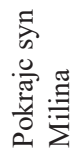 & 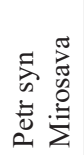 \\
\hline$\stackrel{n}{I}$ & $\stackrel{\circ}{I}$ & 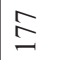 & $\stackrel{\infty}{\beth}$ & $\stackrel{2}{I}$ & $\stackrel{\infty}{\infty}$ & $\infty$ & $\stackrel{\infty}{\infty}$ & $\tilde{\infty}$ & $\underset{\Xi}{ \pm}$ & $\mathscr{\infty}$ & $\stackrel{\infty}{\infty}$ & $\infty$ \\
\hline
\end{tabular}




\begin{tabular}{|c|c|c|c|c|c|c|c|c|c|c|c|c|}
\hline 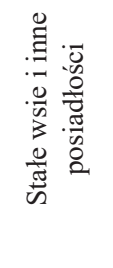 & & & & & & & & & & & 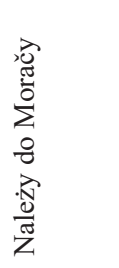 & 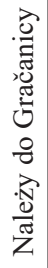 \\
\hline 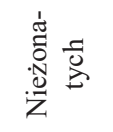 & $m$ & $\nabla$ & $\nabla$ & $m$ & in & & $\nabla$ & $N$ & $\nabla$ & & & \\
\hline $\begin{array}{l}\text { 공 } \\
\text { \& }\end{array}$ & $\cong$ & $\stackrel{\infty}{+}$ & $\triangleright$ & $\hat{m}$ & ‡ & $\tilde{\lambda}$ & $\forall$ & $\ddot{\sim}$ & $\vec{m}$ & $a$ & $\tilde{\lambda}$ & 으 \\
\hline 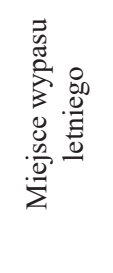 & 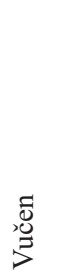 & 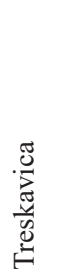 & 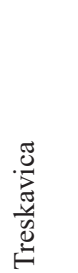 & 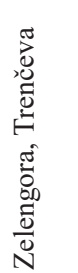 & 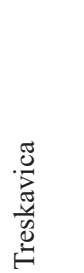 & 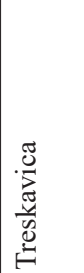 & $\stackrel{\circlearrowright}{ٍ}$ & 总 & 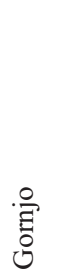 & 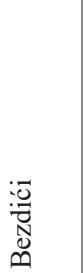 & & \\
\hline 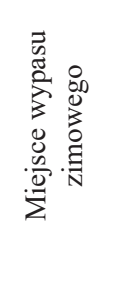 & 前 & $\begin{array}{l}\overrightarrow{E_{0}} \\
\sum_{\Sigma}^{0}\end{array}$ & $\begin{array}{l}\tilde{\ddot{U}} \\
\dot{0} \\
\ddot{\overrightarrow{0}}\end{array}$ & 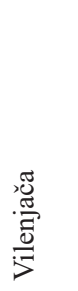 & 胥 & 胥 & 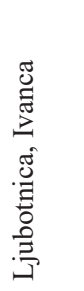 & 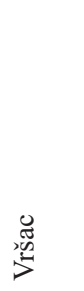 & $\begin{array}{l}\frac{\pi}{\frac{\pi}{2}} \\
\frac{\pi}{0} \\
0\end{array}$ & 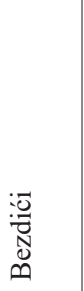 & & \\
\hline 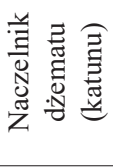 & 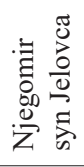 & 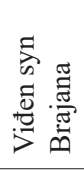 & 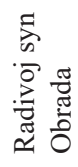 & 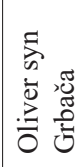 & 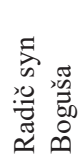 & 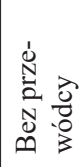 & 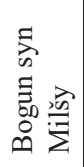 & 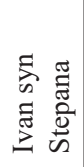 & 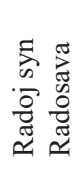 & 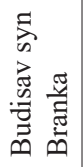 & 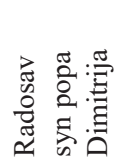 & 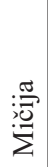 \\
\hline 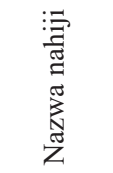 & & & & & & & & & & & & \\
\hline$\dot{\leftrightarrow}$ & $\stackrel{\infty}{\infty}$ & $\infty$ & 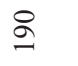 & 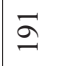 & 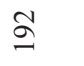 & $\hat{\Omega}$ & ¿ & 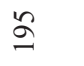 & $\stackrel{\circ}{2}$ & $\hat{a}$ & $\stackrel{\infty}{\varrho}$ & ळ \\
\hline
\end{tabular}




\begin{tabular}{|c|c|c|c|c|c|c|c|c|c|c|c|c|c|c|c|}
\hline 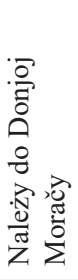 & 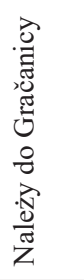 & 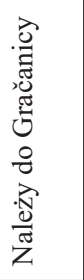 & 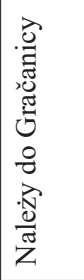 & 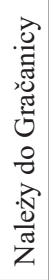 & & 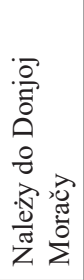 & 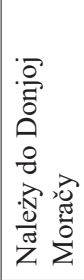 & 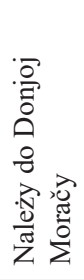 & 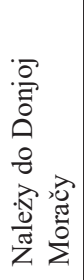 & & & & & & \\
\hline & & & & & & & & & & & & $\sim$ & & & \\
\hline N & $\simeq$ & $m$ & $=$ & $\infty$ & $=$ & 0 & $=$ & ‡ి & $\stackrel{\bullet}{\circ}$ & $n$ & $m$ & 0 & $n$ & $n$ & $\infty$ \\
\hline & & & & & 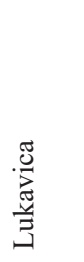 & 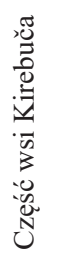 & 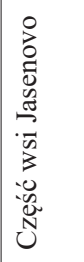 & 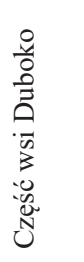 & 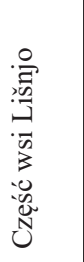 & & & 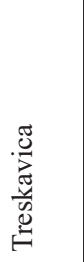 & 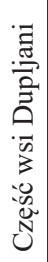 & 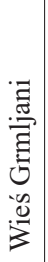 & 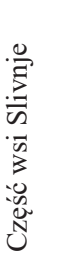 \\
\hline 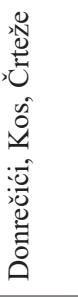 & & & & 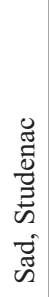 & 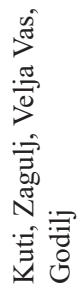 & 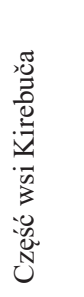 & 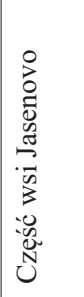 & 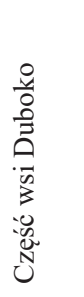 & 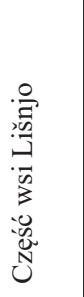 & & & 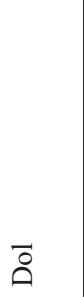 & 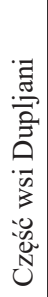 & 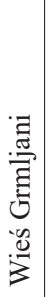 & 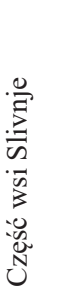 \\
\hline 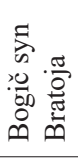 & 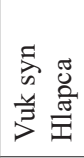 & 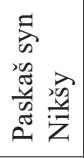 & 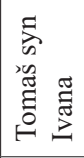 & 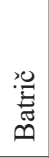 & 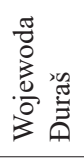 & & & & & 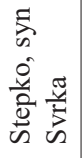 & $\begin{array}{l}\overrightarrow{\tilde{T}} \\
\stackrel{0}{0} \\
\stackrel{3}{\Sigma}\end{array}$ & 党 & : & & $\begin{array}{l}\frac{\pi}{0} \\
0 \\
\frac{0}{0} \\
\frac{0}{0} \\
3 \\
0\end{array}$ \\
\hline 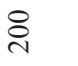 & $\vec{\sim}$ & હิ & $\hat{\stackrel{i}{~}}$ & 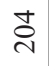 & 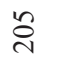 & 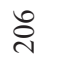 & సิ & $\stackrel{\infty}{\stackrel{\sim}{~}}$ & ڤ્ণ & $\stackrel{\circ}{\stackrel{\sim}{v}}$ & $\overline{\vec{v}}$ & $\stackrel{\sim}{\sim}$ & $\stackrel{m}{\sim}$ & $\underset{\sim}{\Delta}$ & $\frac{n}{\sim}$ \\
\hline
\end{tabular}




\begin{tabular}{|c|c|c|c|c|c|c|c|c|c|c|c|c|}
\hline 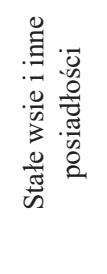 & & & & 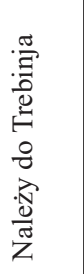 & & & & & & & & \\
\hline 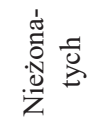 & & & & & & & & & & & & \\
\hline 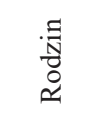 & $n$ & $n$ & $=$ & q & - & - & - & - & $\sim$ & - & - & - \\
\hline 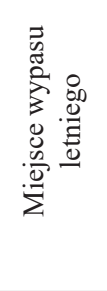 & 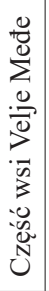 & 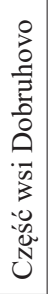 & 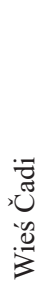 & & & & & & & & & \\
\hline 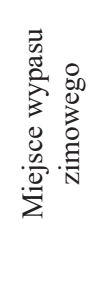 & 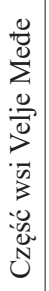 & 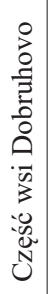 & 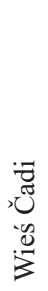 & & 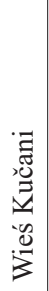 & 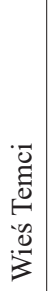 & 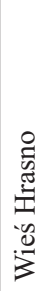 & 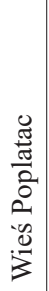 & 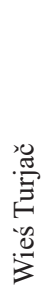 & $\begin{array}{l}\text { त्ञ } \\
0 \\
0 \\
0 \\
3 \\
3\end{array}$ & 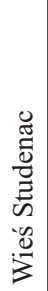 & $\begin{array}{l}0 \\
0 \\
D \\
-\infty \\
0 \\
3 \\
3\end{array}$ \\
\hline 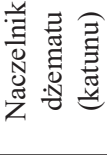 & & & 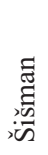 & 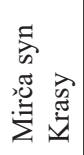 & & & & & & & & \\
\hline 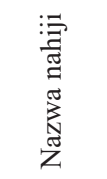 & & & & & & & & & & & & \\
\hline نُ & $\stackrel{\bullet}{\vec{v}}$ & $\overline{\vec{v}}$ & $\stackrel{\infty}{\lambda}$ & $\stackrel{\vec{\lambda}}{\vec{\lambda}}$ & $\stackrel{\mathrm{N}}{ }$ & $\overrightarrow{\widetilde{N}}$ & तี & $\tilde{\mathrm{N}}$ & $\underset{\sim}{\mathbb{Z}}$ & $\stackrel{\sim}{\tilde{N}}$ & $\underset{\sim}{\mathbb{N}}$ & $\widehat{\approx}$ \\
\hline
\end{tabular}




\section{BIBLIOGRAFIA}

\section{Źródła:}

Opširni katastarski popis za oblast Hercegovu iz 1585 godine, sv. 2, dešifrao i sa osmansko-turskog jezika preveo Ahmed S. Aličić, Sarajevo 2014.

Poimečni popis sandžaka vilajeta Hercegovina 1477, priredio Ahmed S. Aličić, Sarajevo 1985.

Sumarni popis sandžaka Bosna iz 1468/69 godine, ed. Ahmed S. Aličić, Mostar 2008.

Literatura:

Hrabak Bogumil, O harcegovačkim vlaškim katunima prema poslovnoj knjizi dubrovčanina Đivana Pripčinivića. "Glasnik Zemaljskog Muzeja”, 11, 1956 [Храбак Б., О хериеговачким влашким катунима према пословной књизи дубровчанина Џивана Припчинивића, «Гласник Земаљског Музеја», 11, 1956], s. 29-39.

Jireček Konstantin, Die Wlachen und Maurowlachen in Denkmäler von Ragusa, Prag, 1879.

Kovačević Desanka, Srednjovekovni katumi po dubrovačkim izvorima, w: Naučno Društvo SR Bosne i Hercegovine, Posebna izdanja Odeljenje istorijsko-filoloških nauka, knjiga 1: Simpozijum o srednjovekovnim katunu održan 24 i 25 novembra 1961 g., urednik Milenko S. Filipović, Sarajevo 1963 [Ковачевић Д., Средњовјековни катуни по дубровачким изворима, w: Научно Друштво СР Босне и Херцеговине, Посебна издања Одељење историјско филолошких наука, књига 1: Симпозијум о средњовековним катуну одржан 24. и 25 новембра 1961 г., уредник Миленко С. Филиповић, Сарајево 1963], s. 121-142.

Kurtović Esad, Seniori hercegovačkih vlaha, w: Hum i Hercegovina kroz povijest. Zbornik radova s međunarodnoga znanstvenog skupa održanog u Mostaru 5. i 6. studenoga 2009, uredio I. Lučić, Zagreb 2011, s. 649-695.

Tošić Đuro, Srednjovekovna humska župa Dabar [Тошић Ђуро, Средњовјековна хумска жупа Дабар], Beograd 2005. 
